Article

\title{
Evaluation and Scale Forecast of Underground Space Resources of Historical and Cultural Cities in China
}

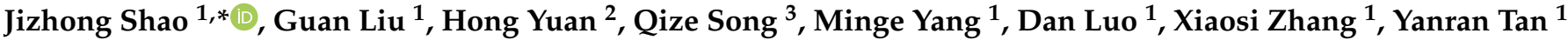 \\ and Yuxin Zhang ${ }^{1}$
}

check for

updates

Citation: Shao, J.; Liu, G.; Yuan, H.; Song, Q.; Yang, M.; Luo, D.; Zhang, X.; Tan, Y.; Zhang, Y. Evaluation and Scale Forecast of Underground Space Resources of Historical and Cultural Cities in China. ISPRS Int. J. Geo-Inf. 2022, 11, 31. https://doi.org/ 10.3390/ijgi11010031

Academic Editor: Wolfgang Kainz

Received: 25 October 2021

Accepted: 26 December 2021

Published: 31 December 2021

Publisher's Note: MDPI stays neutral with regard to jurisdictional claims in published maps and institutional affiliations.

Copyright: (C) 2021 by the authors. Licensee MDPI, Basel, Switzerland. This article is an open access article distributed under the terms and conditions of the Creative Commons Attribution (CC BY) license (https:// creativecommons.org/licenses/by/ $4.0 /)$.
1 Landscape Architecture Department, Huazhong Agricultural University, Wuhan 430070, China; liug9535@nwafu.edu.cn (G.L.); yang17324@webmail.hzau.edu.cn (M.Y.); 2020305120191@webmail.hzau.edu.cn (D.L.); zhangxiaosi@webmail.hzau.edu.cn (X.Z.); 2020305120199@webmail.hzau.edu.cn (Y.T.); 2016305201026@webmail.hzau.edu.cn (Y.Z.)

2 School of Architecture and Design, Southwest Jiaotong University, Chengdu 614202, China; arcyuan@home.swjtu.edu.cn

3 School of Architecture, Nanjing Tech University, Nanjing 210096, China; 201861111008@njtech.edu.cn

* Correspondence: shaojizhong@mail.hzau.edu.cn

\begin{abstract}
Following economic growth in the past three decades, rapid urbanization has caused many pronounced issues, such as spatial scarcity and cultural discontinuity, in Chinese historical and cultural cities. In order to better deal with the diversification of underground space resources, data and information, this study introduces a random forest algorithm and proposes a multi-layer information superposition method. According to the characteristics of different information, starting from qualitative and quantitative aspects, we explore the effective performance of the rational development of underground space resources. Taking Yangzhou City, China, as an example, this paper evaluates the suitability and calculates the development volume of urban underground space. The development capacity, potential value, and comprehensive quality of underground space resources are explored in an attempt to demonstrate the practicality and scientificity of the evaluation method for achieving the developmental goals of urban space reconstruction and historic preservation. On this basis, an underground space scale forecast is carried out to provide decision support for relevant planners, managers, and construction personnel that is conducive to the orderly development of urban space, alleviation of increasing human-land conflicts, and coordination of the protection and development of underground space resources in historical and cultural cities, ultimately promoting sustainable development of cities.
\end{abstract}

Keywords: underground space resources; historical and cultural cities; resources evaluation; scale forecast

\section{Introduction}

Many famous historical and cultural cities in China embody the Chinese nation's long history and rich culture. The Cultural Relics Protection Law promulgated at the end of 1982 stipulates that "famous historical and cultural cities are cities with rich cultural relics, great historical value, and revolutionary significance". In 1984, the Ministry of Construction and the State Administration of Cultural Relics stressed the examination and approval of famous historical and cultural cities, highlighting that we should pay attention not only to the history of the city, but also to whether we have preserved relatively rich and intact cultural relics and intangible culture with great historical, scientific and artistic value. By 7 November 2021, the State Council had promulgated 138 national historical and cultural cities, covering almost most large and medium-sized cities, which is also the object category referred to in this study. However, with the rapid development of urbanisation and the rapid expansion of population, these historical and cultural cities face many problems, such as the contradiction between the shortage of land resources and the 
demand for functional space to varying degrees; the poor quality of residents' basic living environment, the meagre traffic conditions, and the dilapidated or missing infrastructure; and the scarcity of land resources and unlimited expansion of urban boundaries leading to serious damage to the surrounding ecological environment $[1,2]$. This implies that the long history of urban heritage is being confronted with damage caused by massive construction [3] and by the protection of backward development [4]. The sharp conflict between the preservation of urban heritage and the acceleration of urban development is a global challenge with a great number of regional varieties [4]. In the new globalisation of urban heritage, the balance between development and protection has become a central issue for the future sustainable development of famous historical and cultural cities in China. In view of the intrinsic demands of heritage conservation [5] and the extrinsic motivations of urban development [6], the issue of limited land resources in historical and cultural cities has received considerable attention. For this reason, spatially limited historical cities must inaugurate a new direction to find their forms and structures. Underground space, as a potential large-scale space resource in famous historical and cultural cities, is an important component of the urban spatial system and plays a key role in mass transport, heritage conservation, and land savings [7-9]. It opens up broad prospects in strengthening efficient and intensive development, protecting ground features and continuing historical context [10]. The utilisation of underground space resources (USR) aims to address the permanent challenge of accommodating the needs for modernisation and investment in historical and cultural cities without compromising historic character and identity.

\section{Literature Review}

\subsection{Current Research}

Much of the literature since the mid-1950s emphasises transcending the dualism between "renovation" and "preservation" that has been the central aim of historical city development. The faulted "Haussmann's Renovation of Paris" involved the extensive demolition of medieval neighborhoods, streets, open spaces and buildings that, at the time, were deemed overcrowded and unhealthy [11]. As the massive reconstruction and renovation effort concentrated in the historical city, "Urban Revival" or "Urban Regeneration" has revived the economy and diversified the culture [12]. This is well established from a variety of practices of historical city development and heritage management that have placed the historical and contemporary regeneration agenda in context $[13,14]$. To date, several studies have highlighted that historical cities' revitalization requires a long-term commitment to reconfiguring physical space [4], altering perceptions, and transforming the functions of urban space [15].

Since R. Sterling and others have provided effective answers to many common controversial problems in improving urban underground space planning, the research on the development and utilisation of urban underground space has shown a vigorous development trend [16]. The team reviewed a planning study for Minneapolis, Minnesota, in which they investigated the underground spatial distribution and discussed a suitable development path and policy, providing practical guidance for the implementation of underground space planning and related processes [17]. Another study in Australia suggested that the effective and efficient use of urban underground space assists in creating and building a 4-dimensional and more liveable city [18]. Much of the current literature on urban underground spaces pays particular attention to historical cities. Studies have demonstrated that urban underground space has already been implemented within historical cities [19], and have investigated the implications for creating more vibrant neighbourhoods and streets [20]. In another study investigating the planning of underground space in Helsinki, Vähäaho (2014) reported that urban underground space contributed to an aesthetical landscape and friendly environment, offering development opportunities for future generations [21]. Using the approaches of geographic information systems (GIS) and remote sensing systems (RSS) [22], researchers have been able to collate data on under- 
ground geological conditions and existing underground constructions, and evaluate the conditions of exploiting urban underground space development [23].

The studies reviewed here support the hypothesis that urban land resources are absolutely essential to the future sustainable development of historical cities. One possible implication is that the key proven strategies of urban revival for historical cities should focus on improving the allocation and rationalisation of urban space, reconfiguring the distribution and dimensions of vertical space, and raising the awareness and consciousness of planning. Urban underground space can play a significant role in preserving more of historic properties, alleviating the contradiction of urban development and historic preservation, and connecting the fragmented urban spatial structure in which layers of human history and culture stand out in startling juxtaposition [24].

As a consequence of this way of thinking, around the early 1980s small-scale research and case studies began to emerge linking underground space and historical cities. To date, the existing literature on the underground space of historical cities and heritage sites is extensive and focuses particularly on exploring quantitative research methods. Dashko and Karpova (2015) provided an in-depth analysis of various factors, such as the geomorphology, stratigraphy, hydrology, and sedimentology of St. Petersburg, and determine their relevance in evaluating the suitability of underground space development in different districts of St. Petersburg [25]. Following the rapid development of urban underground space in China, further progress has been made in developing research methods for evaluation [26]. Cross-sectional studies have identified particular development models of underground space in allusion to relic classification [27], and evaluated appropriate measures using underground space to protect and promote historic places and valuable heritage sites restricted by surface conditions [28]. While extensive research has been conducted on underground space utilisation, technologies, and practices [29], little attention has been allocated to the systematic concepts and methods by which these resources are investigated and evaluated. Another potential problem is that current urban underground space development in historical cities underestimates the importance of taking heritage values and cultural contexts into account as an initial step [30,31]. Urban USR help historical cities balance environmental sustainability with growth in population and consumption. Accordingly, this research provides forward-looking ideas and proposes innovative strategies for inclusion in urban heritage conservation and underground space development practice, while promoting a specific evaluation tool for particular issues arising from the USR management of historical cities and heritage sites. Qualitative and quantitative research methods were adopted to provide advancing rigour, offer alternatives, and develop rationales.

\subsection{Trend of Research}

Overall, the studies presented thus far provide the vitally important trend that future research is far beyond current observations and extrapolation of existing urban underground space development. Major cities have coordinated comprehensive planning with underground space planning in China, and researched USR development [32,33]. At the same time, some researchers have evaluated the development suitability of USR of historical relics [34]. However, the investigation and evaluation methods did not thoroughly consider the diversified characteristics of information, data, and resources in underground space development of historical and cultural cities. At the same time, the existing research evaluation system is single, mainly focusing on suitability evaluation; research on resource development and utilisation from multiple angles and levels is lacking [34,35]. Therefore, in order to accurately and reasonably understand the USR of historical and cultural cities, this research starts from the three levels of development suitability, development capacity, and scale prediction to realise the reasonable planning and sustainable development of historical and cultural cities. The main research objectives are as follows:

(1) The research of USR needs to bridge quantitative methods with a qualitative approach.

(2) The USR attempt to keep alive the idea of necessary continuity with history and culture. 
(3) The rational and systematic indicators of USR need to consider complex cross-bedding.

\section{Study Area and Data}

\subsection{Study Area}

Yangzhou, a medium-sized city (population exceeding 500,000) in southwest-central Jiangsu Province, China [36], was included in the first batch of "National Famous Historical and Cultural Cities" in 1982, published by the State Council of China [37] (Figure 1A,B). As the capital of the ancient Yangzhou prefecture, Yangzhou City is one of the culturally wealthiest regions in China, with rich aboveground and underground heritage [38]. The city is located to the south of the Jianghuai Plain and the north bank of the Yangtze River, with a latitude of $32^{\circ} 23^{\prime} 49^{\prime \prime} \mathrm{N}$ and a longitude of $119^{\circ} 26^{\prime} 08^{\prime \prime} \mathrm{E}$ [36]. Yangzhou's main urban area of USR evaluation covers an area of $640 \mathrm{~km}^{2}$, with a built-up area of $230 \mathrm{~km}^{2}$ [39]. In consonance with the current economic and social development objectives of Yangzhou City, the shallow USR $(0--15 \mathrm{~m})$ will be essentially used in short-term planning; the sub-shallow USR $(-15--30 \mathrm{~m})$ can be moderately developed in long-term planning; the deep USR $(\geq-30 \mathrm{~m})$ are reserved for the future. Accordingly, our study depth of the USR evaluation in Yangzhou City was principally within $-30 \mathrm{~m}$ of the surface.

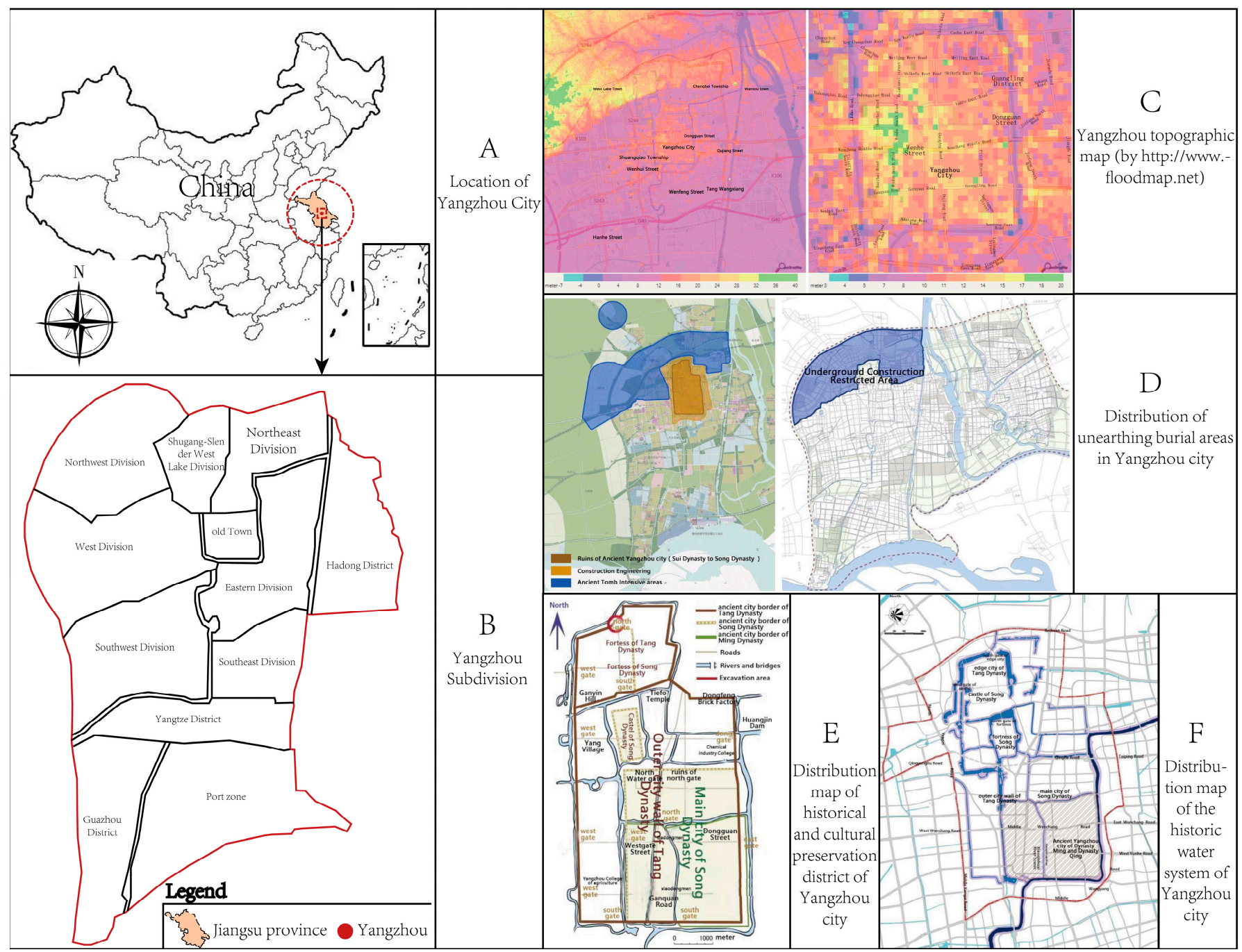

Figure 1. Basic information map of Yangzhou's geographic location and current situation.

The geographical features of Yangzhou City gradually ascend from northeast to east and descend from southwest to southeast. The Jing-Hang Great Canal (from Beijing to Hangzhou) flows through its main urban area [40], leading the inner city of Yangzhou to 
be regarded as a poetic water and canal town [41] with intricate anastomosing streams and lake patterns. It has been conclusively shown that the spatial structure, historic streets, traditional buildings, and picturesque canals from the past determine Yangzhou City's urban tissue and development orientation [36].Yangzhou is located on the plains north of the Yangtze, and the terrain of Yangzhou's main urban area is high in the northwest and low in the southeast, characterised by the alluvial plain of the Yangtze Delta [42]. Over $90 \%$ of the area of Yangzhou is essentially flat with countless rivers and lakes crisscrossing, edged by an $80 \mathrm{~km}$ steady coastline from the Yangtze River. The highest point of Yangzhou City is the Big Copper Mountain, with an elevation of $149.5 \mathrm{~m}$. The area within $3 \mathrm{~km}$ of Yangzhou is $89 \%$ covered by artificial surfaces, the area within $15 \mathrm{~km}$ is $63 \%$ cropland and $23 \%$ artificial surfaces, and the area within $80 \mathrm{~km}$ is $65 \%$ cropland and $15 \%$ artificial surfaces [42]. The west of Shaobo Lake is bounded by the Jianghuai watershed and belongs to the Yangtze River Basin and the Huaihe River Basin. The shape and features of land surfaces gradually decrease from west to east, with elevations ranging from 8 to $40 \mathrm{~m}$ (Figure 1C). The east of Shaobo Lake is flat, with elevations from 2.5 to $6.0 \mathrm{~m}$ Figure 1C. It is divided into five zones from south to north: the polder area along the river $\left(83.26 \mathrm{~km}^{2}\right)$, the Tongnan-Gaosha area $\left(364.14 \mathrm{~km}^{2}\right)$, the Tongbei-Gaoping area $\left(352.31 \mathrm{~km}^{2}\right)$, the Irrigation area $\left(189.96 \mathrm{~km}^{2}\right)$, and the Lixia river polder area $\left(340.50 \mathrm{~km}^{2}\right)$.

The development of urban construction during various historical periods in Yangzhou has formed existing urban tissue in its evolving history [43]. The ancient city, cultural relics, historic canals, and the picturesque Slender West Lake are urban spatial characteristics associated with "pursuing the city by water and overlaying through past dynasties" [44]. Yangzhou's main urban areas are rich in regional culture, consisting of traditional blocks and streets, ancient urban fabric, and historic water systems, and its overall preservation is relatively intact. The unearthed burial areas are mainly concentrated in the northwestern part of Yangzhou's main city, including the relic site of Yangzhou City (including Songiiacheng, Tangzicheng, Slender West Lake Scenic Area, historic ancient town, etc.), Ganquan-Yangmiao burial areas, tomb areas from the Warring States period to the Five Dynasties and Ten Kingdoms period, burial and tomb areas from the Tang and Song Dynasties in the east of the central city, residential areas from the Han Dynasty in the north of the central city, palaces from the Sui Dynasty, and temples from the Tang and Song Dynasties (Figure 1D) [45]. For the evaluation of the USR, the historic city and streets were preserved as the restricted construction areas of the USR. The key historic sites, heritage, and relics were identified as prohibited construction areas of the USR (Figure 1E,F).

\subsection{Data Collection}

The basic data of this study are mainly from the "Resource Status Distribution Map," "Distribution map of buried objects in Yangzhou", "Geological map of Yangzhou", "Evaluation Report on Underground Water Resources in Yangzhou City, Jiangsu Province", "Yangzhou City Master Plan", "Yangzhou City Comprehensive Transportation Plan," "Yangzhou City Recent Construction Plan", "Yangzhou City Historical and Cultural City", "Conservation Plan (2001-2020)", "Yangzhou City Urban Drainage Plan", "Yangzhou City Status and Planned Construction Land Summary Table (2002-2020)", etc. The Yangzhou City Air Defense Office provided the type, area, quantity, etc., of the current underground space. At the same time, we conducted a field investigation on the current situation of the existing underground space and reviewed the actual utilisation of the underground space, etc.

\section{Multi-Layer Information Superposition Method}

The development and utilization of USR in famous historical and cultural cities involve physical space, historical culture, buried objects, natural resources, etc., which have the characteristics of diversified information. Therefore, this study proposes a multi-layer information superposition method to solve the problem of underground space resource evaluation and scale prediction of historical and cultural cities with multi-information 
interwoven (Figure 2). The method mainly includes three steps (Figure 3). The first step is to evaluate the suitability of resources using the social network analysis method, Delphi method, interpretive structure model method, random forest algorithm, and fuzzy comprehensive evaluation method to rationalize the utilisation of resources, improve decision making, and reduce land waste. The second step is to use the capacity model to calculate the development potential of underground space based on suitability evaluation. The third step is to use the demand model to calculate the demand. On this basis, combined with the suitability evaluation results, we use the value model to calculate the value, and then predict the scale, so as to provide a more feasible implementation scheme for the planning. In addition, GIS is used to evaluate statistics and to analyse and visualise the process data.

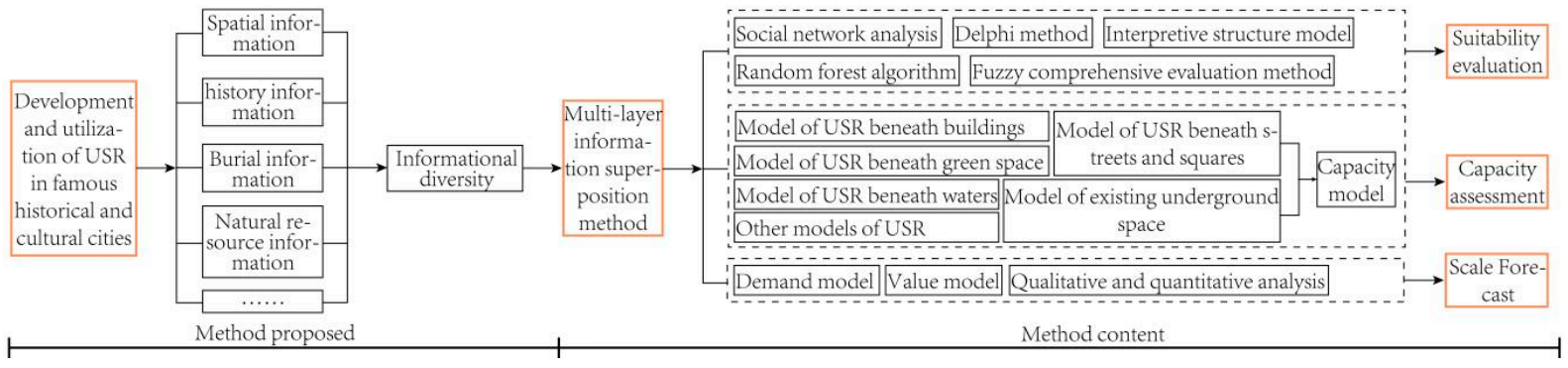

Figure 2. Origin of multi-layer information superposition method.

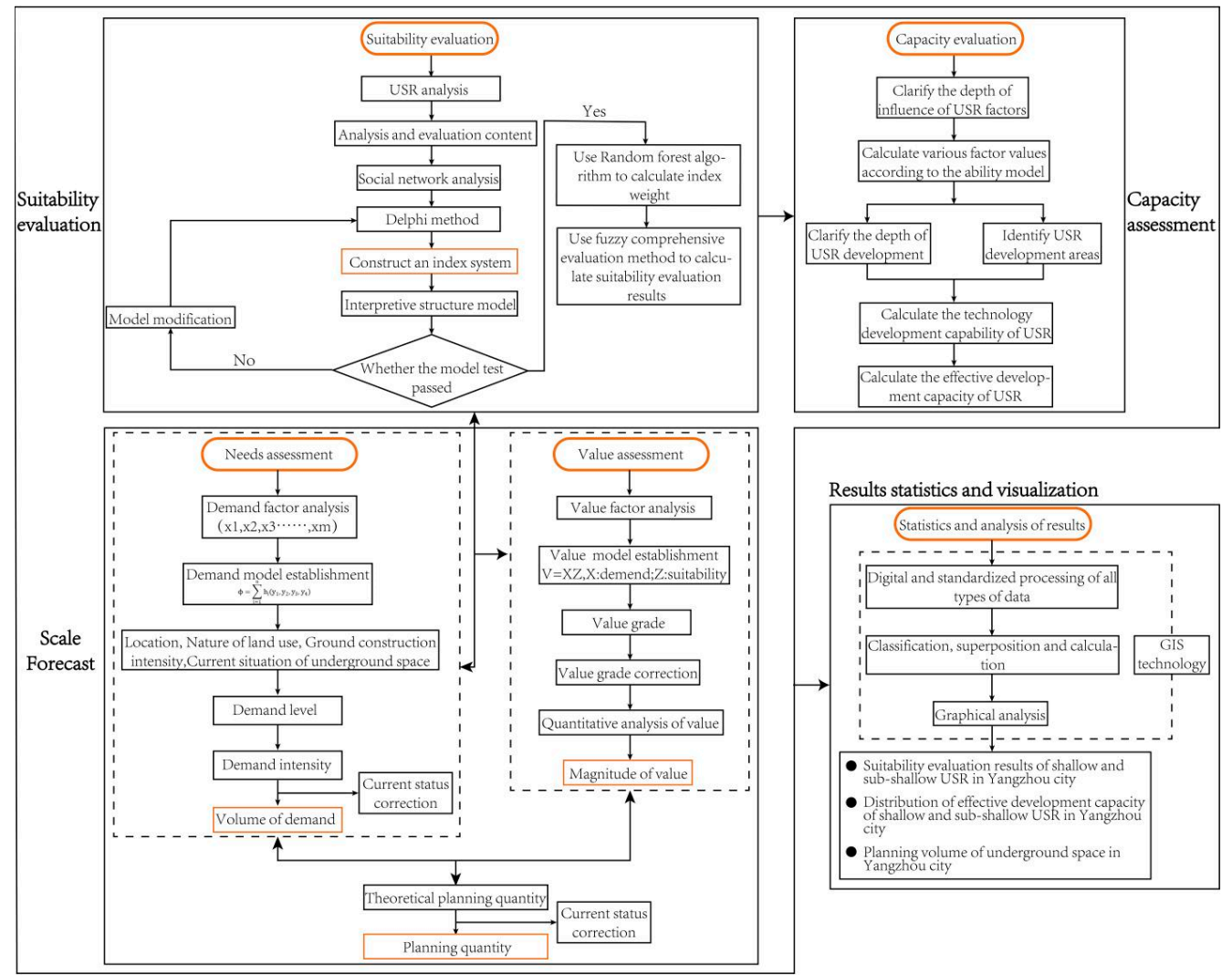

Figure 3. The framework of multi-layer information superposition method.

\subsection{Suitability Evaluation}

\subsubsection{Index System Construction}

Based on an in-depth comparison and systematic analysis of the city USR evaluation literature, we use the social network analysis method, which represents the essence of expert research results, and statistically infer large samples and add relational factors to 
screen out the 29 evaluation systems related to this research. The results are converted into binary matrix (Appendix A). The presence of a relationship is 1 , the absence of a relationship is 0 [46]. The first-level indicators are established as the relationship matrix. The data visualisation is carried out using the network analysis software gephi to obtain the three first-level indicators with the highest utilisation rate. The network analysis is carried out on the three first-level indicators to obtain the second-level indicators with the highest utilisation rate corresponding to each first-level indicator. The indicators are supplemented in combination with the characteristics of famous historical and cultural cities, and the existing indicators are corrected by the Delphi method to obtain the qualitative index system (Figure 4 ).

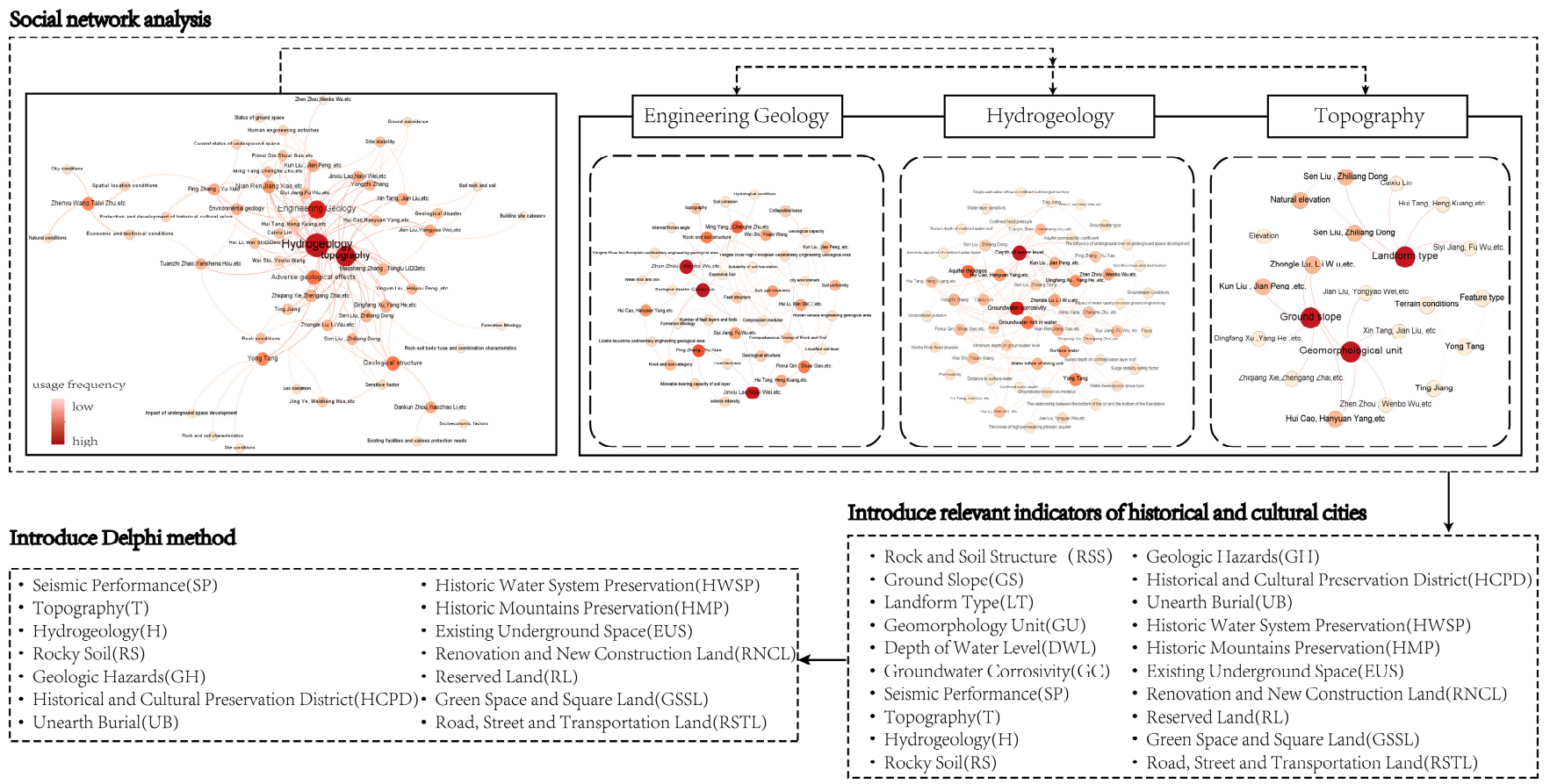

Figure 4. Construction process of qualitative index system.

On this basis, the quantitative interpretation structural model method (ISM) is used to verify the scientificity of the qualitative index system [47]. The specific steps include inviting 30 experts and graduate students related to urban planning and underground space to conduct a questionnaire survey, calculate the correlation rate between various indicators, obtain the upper triangular relationship between secondary and tertiary indicators so as to obtain the adjacency matrix and reachability matrix, and then obtain the membership relationship diagram between indicators (Figure 5). On this basis, compared with the constructed qualitative index system, it is found that the qualitative index system is consistent with the quantitative index system, which can be used for further research. Four primary indicators and 14 secondary indicators were obtained (Table 1). 


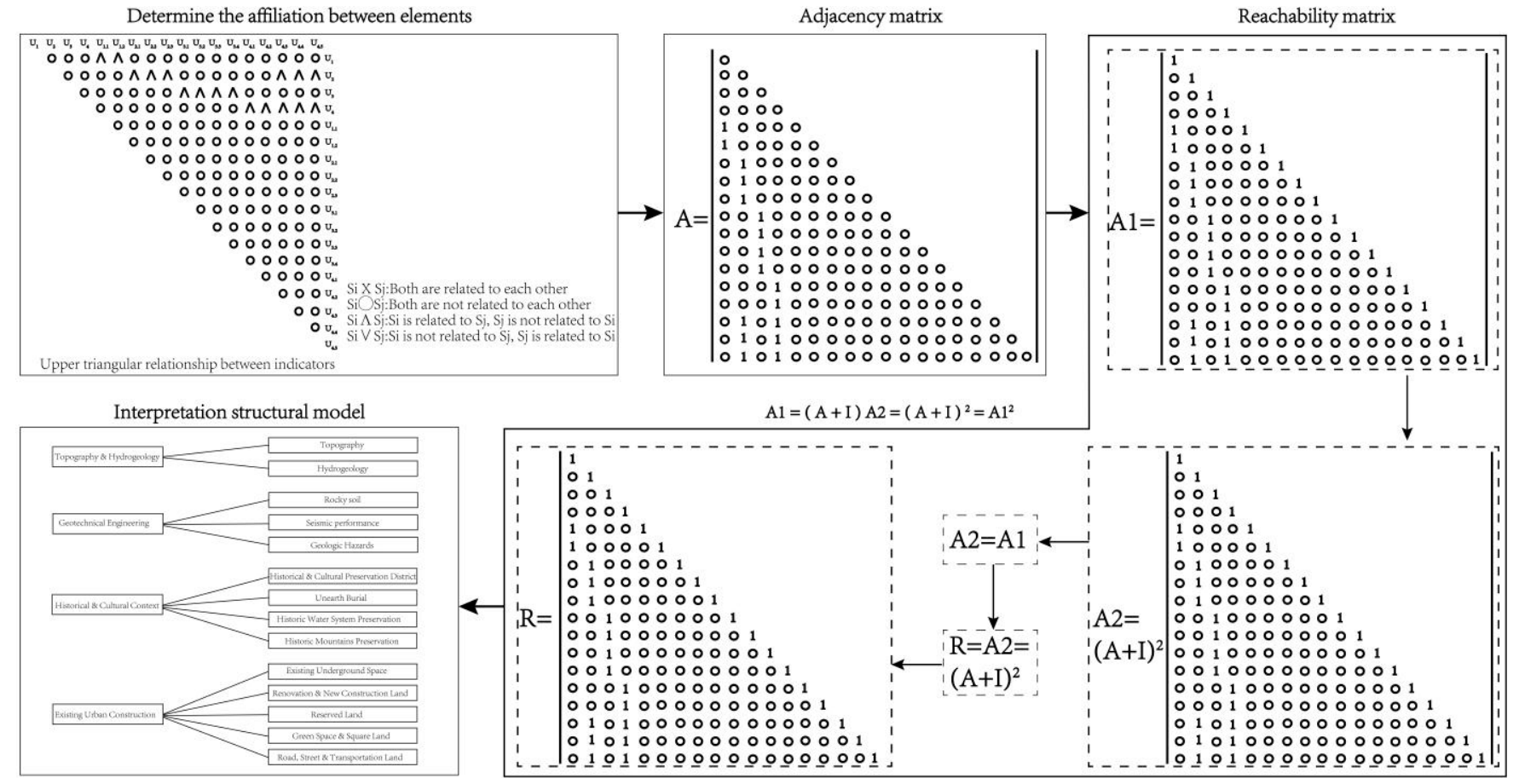

Figure 5. ISM method flow chart.

Table 1. Suitability evaluation index of USR.

Index Level 1

Index Level 2

Indicators Description

The elevation, slope, and orientation of topographic features greatly impact the implementation of underground space construction, divided by the topographic slope. A. $0-5 \%$ is suitable for underground space constructions; B. $15-20 \%$ is basically suitable for underground space constructions;

C. $20-30 \%$ is unsuitable for underground space constructions;

D. $30-35 \%$ strictly prevents underground space constructions.

Suitability of dividing underground space by groundwater inflow of single well (Q). A. Q $<100$ has little impact on

$\mathrm{U}_{1} \quad$ Topography and Hydrogeology underground space, simple construction and maintenance, and is low-cost, so that it is more suitable for underground space development; B. $100<\mathrm{Q}<400$ has little impact on underground space, so that waterproof treatment measures need to be taken,

$\mathrm{U}_{1.2} \quad$ Hydrogeology * which make it suitable for underground space development;

C. $400<\mathrm{Q}<700$ has a great impact on underground space construction and maintenance, a high cost and general suitability for underground space development;

D. $700<Q<1000$ is not suitable for underground space development; E. $Q>1000$, is extremely unsuitable for underground space development. 
Table 1. Cont.

\begin{tabular}{|c|c|c|c|c|}
\hline & Index Level 1 & & Index Level 2 & Indicators Description \\
\hline \multirow[b]{3}{*}{$\mathrm{U}_{2}$} & \multirow[b]{3}{*}{$\begin{array}{l}\text { Geotechnical } \\
\text { Engineering }\end{array}$} & $\mathrm{U}_{2.1}$ & Rocky soil & $\begin{array}{l}\text { According to the different classifications of a rock stratum } \\
\text { (Table 2) and soil (Table 3) in the engineering geology of rock } \\
\text { and soil mass and their impact on the development and } \\
\text { utilisation of underground space, the evaluation criteria are } \\
\text { divided into four grades: excellent, very good, good, and poor. }\end{array}$ \\
\hline & & $\mathrm{U}_{2.2}$ & Seismic performance & $\begin{array}{l}\text { According to different seismic performance, the topographical } \\
\text { space selection site can be divided into three categories: } \\
\text { "favourable sites, unfavourable sites, and dangerous sites" } \\
\text { (Table } 4 \text { ). }\end{array}$ \\
\hline & & $\mathrm{U}_{2.3}$ & Geologic Hazards & $\begin{array}{l}\text { Geological disasters that significantly impacted the } \\
\text { development of USR are mainly adverse geological conditions } \\
\text { and seismic fault zones. In terms of unfavourable geology, the } \\
\text { impact of collapse geological disaster area on underground } \\
\text { space is mainly manifested in the collapse point on the river } \\
\text { bank, which is not suitable for the development and utilisation } \\
\text { of shallow underground space. The underground space can be } \\
\text { developed and utilised after planning, site selection, and } \\
\text { engineering measures are taken in the collapse prone area. For } \\
\text { the collapse prone area treated by engineering measures, it is } \\
\text { still not suitable to set up underground public space with } \\
\text { concentrated pedestrian flow. In terms of the seismic fault zone, } \\
\text { the regional stability of inactive fault structure is good, and its } \\
\text { impact on underground space development is relatively small. } \\
\text { The regional stability of active fault structure is poor and there is } \\
\text { a certain possibility of a sudden earthquake, which has a great } \\
\text { impact on the development of underground space. }\end{array}$ \\
\hline \multirow{4}{*}{$\mathrm{U}_{3}$} & \multirow{4}{*}{$\begin{array}{l}\text { Historical and } \\
\text { Cultural Context }\end{array}$} & $\mathrm{U}_{3.1}$ & $\begin{array}{l}\text { Historical and Cultural } \\
\text { Preservation District }\end{array}$ & $\begin{array}{l}\text { The impact assessment of underground space shows that the } \\
\text { protection scope of famous historical cities and historical and } \\
\text { cultural blocks is the restricted area of underground space. The } \\
\text { protection scope of cultural relics protection units is the } \\
\text { prohibited area of underground space. }\end{array}$ \\
\hline & & $\mathrm{U}_{3.2}$ & Unearth Burial & $\begin{array}{l}\text { The impact assessment of underground space is divided into } \\
\text { areas with dense underground burial, many scenic spots and } \\
\text { historic sites on the ground, and many buried objects } \\
\text { underground, which are restricted areas for underground } \\
\text { space development. }\end{array}$ \\
\hline & & $\mathrm{U}_{3.3}$ & $\begin{array}{c}\text { Historic Water System } \\
\text { Preservation }\end{array}$ & $\begin{array}{l}\text { In the development and construction of underground space, it } \\
\text { should be strictly controlled and protected underground space } \\
\text { under the historical water system. In principle, it should be used } \\
\text { as an underground-space-restricted construction area. }\end{array}$ \\
\hline & & $\mathrm{U}_{3.4}$ & $\begin{array}{l}\text { Historic Mountains } \\
\text { Preservation }\end{array}$ & $\begin{array}{l}\text { Historic mountains preservation areas should be principally } \\
\text { regarded as restricted construction areas for urban underground } \\
\text { space development. }\end{array}$ \\
\hline
\end{tabular}


Table 1. Cont.

\begin{tabular}{|c|c|c|c|c|}
\hline & \multirow{2}{*}{\multicolumn{2}{|c|}{$\begin{array}{l}\text { Index Level } 1 \\
\qquad \\
\qquad \mathrm{U}_{4.1}\end{array}$}} & \multirow{2}{*}{$\begin{array}{l}\text { Index Level } 2 \\
\text { Existing Underground } \\
\text { Space }\end{array}$} & \multirow[b]{2}{*}{$\begin{array}{l}\text { Indicators Description } \\
\text { In order to ensure the stability of the rock and soil protected by } \\
\text { the existing underground space, the USR within a certain range } \\
\text { should be classified as unsuitable areas for development. In } \\
\text { such ways, approximately } 4.13 \text { million } \mathrm{m}^{2} \text { of underground space } \\
\text { in Yangzhou City is unavailable for future development } \\
\text { involved in the evaluation process of USR. }\end{array}$} \\
\hline & \multirow[t]{5}{*}{ (1) } & & & \\
\hline & & $\mathrm{U}_{4.2}$ & $\begin{array}{l}\text { Renovation and New } \\
\text { Construction Land }\end{array}$ & $\begin{array}{l}\text { Excluding the current reserved land and current underground } \\
\text { space land, the distribution of renewal and reconstruction and of } \\
\text { new land is determined according to the comparison of land use } \\
\text { status and planning. Such new and reconstruction land actively } \\
\text { promotes the development and construction of underground } \\
\text { space; however, it should be noted that building floor height has } \\
\text { a certain impact on underground space. With the increase of } \\
\text { building floor height, the suitability of underground space } \\
\text { becomes worse. }\end{array}$ \\
\hline & & $\mathrm{U}_{4.3}$ & Reserved Land & $\begin{array}{l}\text { Should almost be restricted, except for special circumstances } \\
\text { such as underground railway crossing. }\end{array}$ \\
\hline & & $\mathrm{U}_{4.4}$ & $\begin{array}{l}\text { Green Space and } \\
\text { Square Land }\end{array}$ & $\begin{array}{l}\text { Protected green space and ecological green space are forbidden } \\
\text { to be constructed in underground space; park green space is } \\
\text { suitable for construction or restricted construction based on } \\
\text { demand; square land is very suitable for the development and } \\
\text { construction of underground space. }\end{array}$ \\
\hline & & $\mathrm{U}_{4.5}$ & $\begin{array}{l}\text { Road, Street and } \\
\text { Transportation Land }\end{array}$ & $\begin{array}{l}\text { The USR of underground pedestrian crossings, underground } \\
\text { commercial streets, utility tunnels, and parking are } \\
\text { regarded as suitable construction areas for urban } \\
\text { underground space development. }\end{array}$ \\
\hline
\end{tabular}

Note: Mark "*" for quantitative indicators.

Table 2. Evaluation index of rock mechanics.

\begin{tabular}{ccc}
\hline Rock Mass Type & Rock Strength and Bedrock Properties & Appraisal Grades \\
\hline Massive Structure & hard rock, sub-hard rock, sub-soft rock, soft rock & excellent \\
\hline Laminar Structure & $\begin{array}{c}\text { without a weak interlayer } \\
\text { without a weak interlayer, good interlayer bonding } \\
\text { without a weak interlayer, bad interlayer bonding } \\
\text { with a weak interlayer }\end{array}$ & $\begin{array}{c}\text { very good } \\
\text { good } \\
\text { poor }\end{array}$ \\
\hline Fragmented Structure & $\begin{array}{c}\text { mosaic texture } \\
\text { other textures }\end{array}$ & $\begin{array}{c}\text { very good } \\
\text { poor }\end{array}$ \\
\hline Granular Structure & shale, rock dust, detritus & poor \\
\hline Rock folds and Faults & & poor \\
\hline
\end{tabular}

Table 3. Evaluation index of soil mechanics.

\begin{tabular}{ccc}
\hline Soil Type & Grain Size Range (mm) USCS & Appraisal Grades \\
\hline Gravel and sand & gravel 76.2 to $4.75 ;$ sand 4.75 to 0.075 & excellent \\
\hline Silt and partially saturated clay & & very good \\
Saturated clay & Fines $<0.075$ & good \\
Saturated soft clay & & poor \\
\hline
\end{tabular}


Table 4. Evaluation index of seismic performance.

\begin{tabular}{ccc}
\hline Location & Site Features & Appraisal Grades \\
\hline Favorable sites & $\begin{array}{c}\text { stable bedrock, hard soil, open, flat, dense, } \\
\text { and uniform medium-hard soil, etc. }\end{array}$ & very good \\
\hline Unfavorable sites & $\begin{array}{c}\text { weak soil, liquefied soil, high and isolated } \\
\text { hill, non-rock slope, the edge of bank and } \\
\text { slope, inhomogeneous soil, etc. }\end{array}$ & good \\
\hline Dangerous sites & $\begin{array}{c}\text { landslide, collapse, subsidence, ground } \\
\text { rupture, soil liquefaction, rock falls, debris } \\
\text { flows, and seismic fault, etc. }\end{array}$ & poor \\
\hline
\end{tabular}

\subsubsection{Evaluation Result Calculation}

In order to closely combine the weight calculation results with the factors affecting USR potential and the characteristics of famous historical and cultural cities, this study selects 36 cities, such as Xi'an, Nanjing and Suzhou, among the 138 famous historical and cultural cities in China, and selects a total of 100 historical and cultural streets in each city as training samples. Then, we create data flow files with the help of IBM SPSS Modeler software, sets type nodes, and constructs trees through CART. The bagging technique is used to randomly select the input indicators and finally generate the importance of variables to obtain the indicator weight (Figure 6). On this basis, a fuzzy comprehensive evaluation method was used to obtain suitability evaluation results, allowing more of the uncertainties inherent in the rating process to be captured and retained [48]. The established procedures of the suitability evaluation model of the USR are outlined in the following steps (Figure 7).

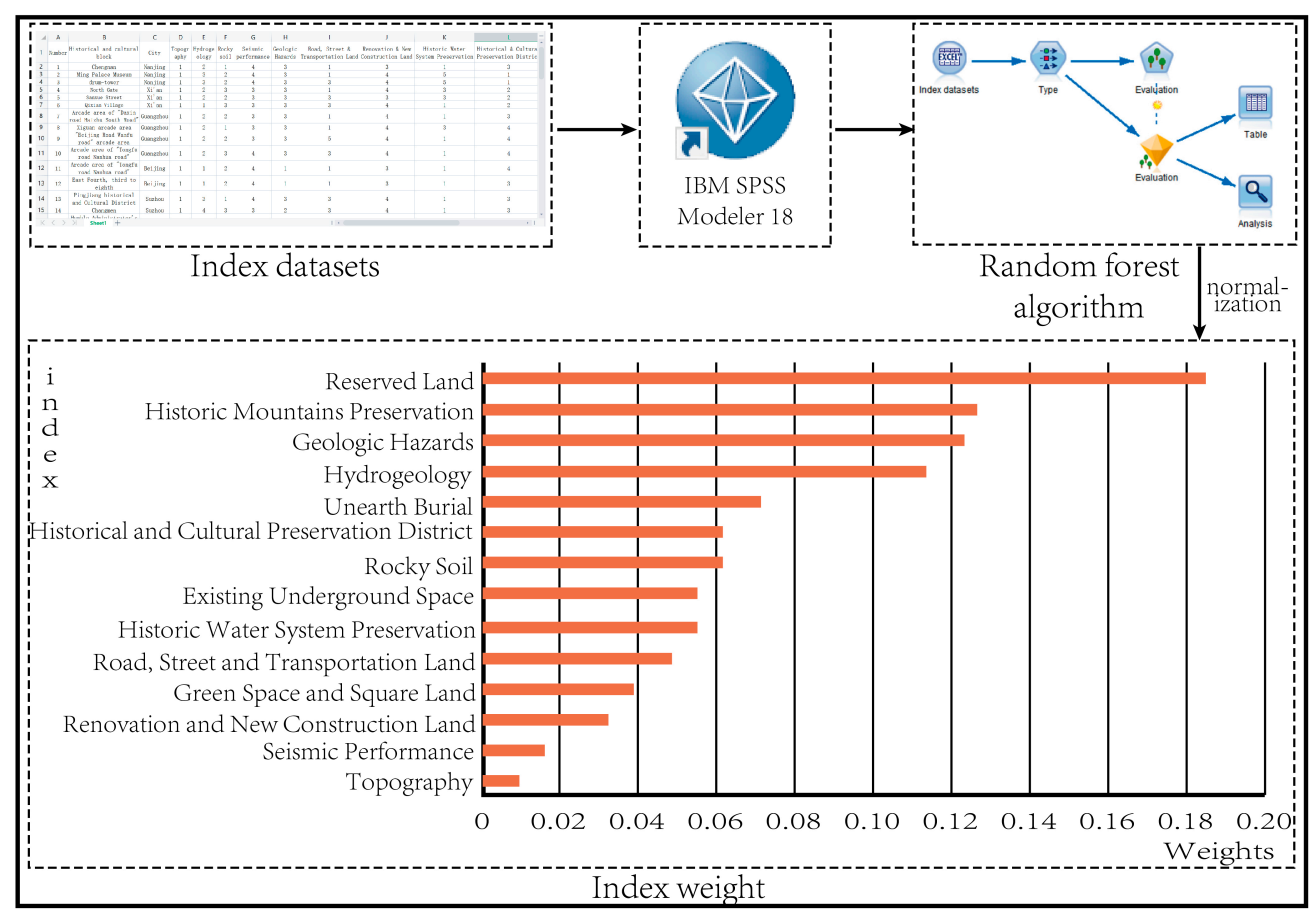

Figure 6. Index weights calculation process. 


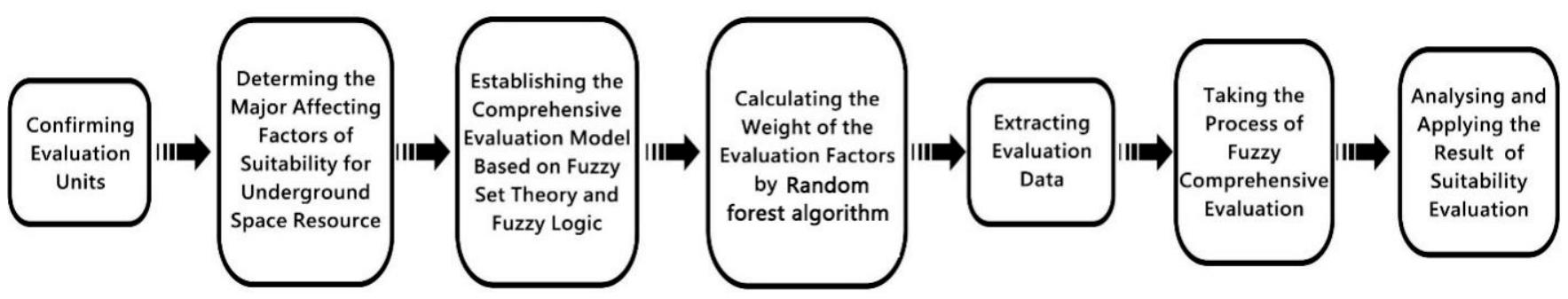

Figure 7. Process of suitability evaluation of USR.

(1) The set of objects, factors, and grades

To begin this process, the set of evaluation objects can be represented as a vector $\mathcal{X}=$ $\left\{x_{1}, x_{2}, \cdots, x_{n}\right\}$. The evaluation factors were defined according to the established evaluation index. A set of $n$ evaluation factors can be represented as a vector $U=\left\{u_{1}, u_{2}, \cdots, u_{n}\right\}$. Then, the appraisal set can be represented as a vector $V=\left\{v, v_{2}, \cdots, v_{m}\right\}$, in which $m$ represents the number of levels in the appraisal (Table 5).

Table 5. The set of evaluation factors and the set of appraisal grades.

\begin{tabular}{cccccc}
\hline & $\mathcal{V}_{1}$ & $\mathcal{V}_{2}$ & $\ldots$ & $\mathcal{V}_{m-1}$ & $\mathcal{V}_{m}$ \\
\hline $\mathcal{U}_{\mathbf{1}}$ & $a_{11}\left(a_{10} \sim a_{11}\right)$ & $a_{12}\left(a_{11} \sim a_{12}\right)$ & $\ldots$ & $a_{1 m-1}\left(a_{1 m-2} \sim a_{1 m-1}\right)$ & $a_{1 m}\left(a_{1 m-1} \sim a_{1 m}\right)$ \\
$\mathcal{U}_{\mathbf{2}}$ & $a_{21}\left(a_{20} \sim a_{21}\right)$ & $a_{22}\left(a_{20} \sim a_{22}\right)$ & $\ldots$ & $a_{2 m-1}\left(a_{2 m-2} \sim a_{2 m-1}\right)$ & $a_{2 m}\left(a_{2 m-1} \sim a_{2 m}\right)$ \\
$\ldots$ & $\ldots$ & $\ldots$ & $\ldots$ & $\ldots$ & $\ldots$ \\
$\mathcal{U}_{\mathbf{n}-1}$ & $a_{n-11}\left(a_{n-10} \sim a_{n-11}\right)$ & $a_{n-12}\left(a_{n-11} \sim a_{n-12}\right)$ & $\ldots$ & $a_{n-1 m-1}\left(a_{n-1} m-2 \sim a_{n-1}\right)$ & $a_{n-1}\left(a_{n-1}\right)$ \\
$\mathcal{U}_{\mathbf{n}}$ & $a_{n 1}\left(a_{n 1} \sim a_{n 1}\right)$ & $a_{n 2}\left(a_{n 1} \sim a_{n 2}\right)$ & $\ldots$ & $a_{n m a 1}\left(a_{n m-2} \sim a_{n m-1}\right)$ & $\left.a_{n-1}\right)$ \\
\hline
\end{tabular}

(2) Membership function and mapping matrix

In the conventional view of statisticians, the membership function and mapping matrix can be used in a wide range of domains in which information is incomplete or imprecise. The second step was used to identify the membership function, and the mapping matrix involved the suitability evaluation model of the USR.

For $\alpha_{i j}$, if the value is $\geq \alpha_{i j}$, then $\alpha_{i 1} \geq \alpha_{i 2} \geq \cdots \geq \alpha_{i m}$, the membership function is:

$$
\begin{gathered}
\mu_{i 1}(x)=\left\{\begin{array}{c}
1, x \geq a_{i 1} \\
\left(\frac{a_{i 2}-x}{a_{i 2}-a_{i 1}}\right)^{\delta}, a_{i 2} \leq x<a_{i 1} \\
0, x \geq a_{i 2}
\end{array}\right. \\
\mu_{i j}(x)=\left\{\begin{array}{c}
\left(\frac{a_{i, j}-2}{x}\right)^{\delta}, x \geq a_{i, j}-1 \\
\left(\frac{a_{i, j+1}-x}{a_{i, j+1}-a_{i j}}\right)^{\delta}, a_{i, j+1} \leq x<a_{i j}, j=2, \cdots, m-1
\end{array}\right. \\
\mu_{i m}(x)=\left\{\begin{array}{c}
\left(\frac{a_{i, m-1}}{x}\right)^{\delta}, x \geq a_{i, m-1} \\
1, a_{i m} \leq x \leq a_{i, m-1} \\
\left(\frac{x}{a_{i m}}\right)^{\delta}, x<a_{i m}
\end{array}\right.
\end{gathered}
$$

(3) Establish a fuzzy mapping matrix

The objective of the suitability evaluation process is to determine a mapping from $U$ to $V$. For a specific factor $u_{i}$, fuzzy mapping to the appraisal vector $V$ can be represented 
by the vector $R_{i}=\left\{r_{i 1}, r_{i 2}, \ldots, r_{i k}, \ldots, r_{i m}\right\}$, where $m$ represents the number of levels in the appraisal and $r_{i k}$ represents the fuzzy membership degree of appraisal factor $i$ to grade $k$. For each object $x_{k}$ to be evaluated, for each quality factor $u_{i}$, there is a measured value $y_{i}$ that corresponds to the measured index vector $Y_{k}=\left(y_{1}, y_{2}, \ldots, y_{n}\right)$ of $x k$; thus, $u_{i j}\left(y_{i}\right)$ can indicate the degree of $x_{k}$ toward $v_{i}$ relative to the factor $u_{i}$.

In general, the fuzzy appraisal matrix of all $n$ factors can be derived and represented as a matrix $R$, such that if there are $n$ factors and $m$ levels of appraisal grades,

$$
R_{k}=\left[\begin{array}{cccc}
\mu_{11}\left(y_{1}\right) & \mu_{12}\left(y_{1}\right) & \ldots & \mu_{1 \mathrm{~m}}\left(y_{1}\right) \\
\mu_{21}\left(y_{2}\right) & \mu_{22}\left(y_{2}\right) & \ldots & \mu_{2 \mathrm{~m}}\left(y_{2}\right) \\
\ldots & \ldots & \ldots & \ldots \\
\mu_{\mathrm{n} 1}\left(y_{n}\right) & \mu_{\mathrm{n} 2}\left(y_{n}\right) & \ldots & \mu_{\mathrm{nm}}\left(y_{m}\right)
\end{array}\right]_{n x m}
$$

$R_{k}$ is the fuzzy relationship matrix between $U$ and $V$ of $x_{k}$. In the above matrix notation for $R$, each row represents the set of appraisal membership degrees to the corresponding appraisal vector $V$ for each evaluation factor $u_{i}$ in evaluation vector $U$.

(4) The weight of the evaluation factor

To obtain a comprehensive usability evaluation, the relative importance of each evaluation factor on the overall grading of the product should be quantified. The weight vector can be represented by $A$, calculated using the random forest algorithm. For $n$ evaluation factors, the weight can be represented by the vector $A=\left(a_{1}, a_{2}, \ldots, a_{n}\right)$, in which the sum of all elements equals 1 .

$$
A=\left(a_{1}, a_{2}, \cdots, a_{n}\right) a_{i} \in[0,1] \sum_{i=1}^{n} a_{i}=1
$$

\section{(5) The overall appraisal result}

The overall appraisal result can be obtained by taking into account the relative weights of each evaluation factor, such that a single vector with the same level of appraisal grade $m$ can be represented by:

$$
B_{k}=A \circ R_{k}=\left(b_{1}, b_{2}, \ldots, b_{m}\right)
$$

The main factor prominent synthetic operator:

$$
\mathrm{b}_{j}=\bigvee_{i=1}^{n}\left(a_{i} r_{i j}\right), j=1,2, \ldots, m
$$

It can be used in a functional model. Compared with the traditional operator, the advantage of the prominent factor synthetic operator is that it can protect the integrity of the information.

It not only highlights the main factors, but also highlights the membership of the singlefactor evaluation. According to the principle of maximum subordination, if $b_{j 0}=\max _{1 \leq j \leq m} b_{j}$, then $x_{k}$ belongs to $v_{\mathrm{j} 0}$.

Finally, the established evaluation set is the summarised evaluation level. In this study, the evaluation set of USR is selected as six levels $m=6$, and the appraisal vector can be represented as $V=\left\{v, v_{2}, \cdots, v_{m}\right\}=\{\mathrm{I}$ is excellent, II is very good, III is good, IV is poor, $\mathrm{V}$ is very poor, $\mathrm{VI}$ is extremely poor $\}$.

\subsection{Capacity Evaluation}

The capacity theory of USR is the resource partition amount of urban underground space, including the four following concepts: the theoretical potentiality, the technical exploitation, the effective development, and the actual utilisation of USR. Figure 8 illustrates the critical characteristic of the subordination relation and inclusion relation between the several types of USR. The number of upper-level resources contains the number of resources in the lower level [49]. 
(1) Theoretical potentiality of USR: the total theoretical capacity beneath the surface of the earth within the study area, including both exploited and residual capacities.

(2) Technical exploitation of USR: the total amount of space beneath the ground surface that can be constructed by existing engineering technologies within the study area, which is not affected by constraints such as various topography, urban development, and construction condition.

(3) Effective development of USR: the capacity is potentially available for development and construction with the reasonable development density, the various influencing factors, and the land value.

(4) Actual utilisation of USR: the actual underground space construction under the condition of satisfying all constraints, such as historical and cultural protection, ecological environment coordination, and urban development demand.

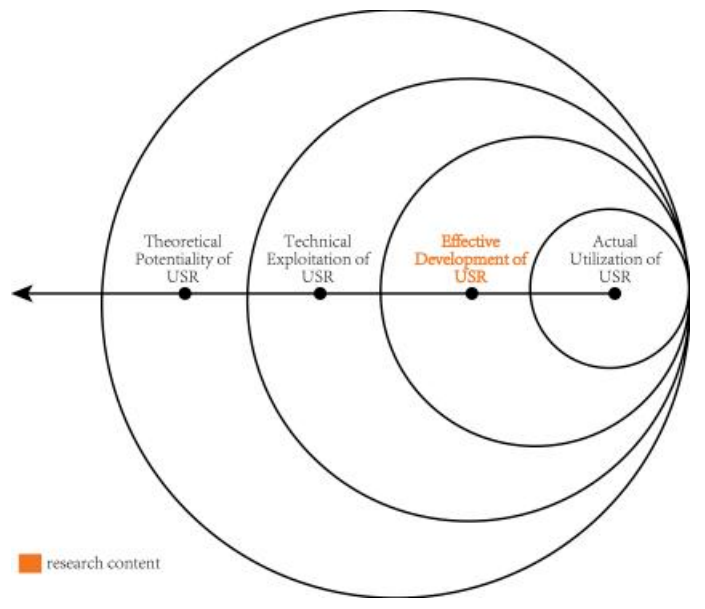

Figure 8. Subordination and inclusion relation of USR.

When investigating and analysing the development and utilisation range of USR, it is often necessary to first determine the available range of resources, further explore the development difficulty of USR within the available range, and finally obtain the capacity that can be effectively developed and utilised. Therefore, Tong Linxu and other scholars have slightly adjusted the above definition: the amount of USR available for reasonable development refers to the extent of USR within the natural reserve area of USR, excluding the distribution of adverse geological conditions and geological disaster risk areas, ecological and natural protection in forbidden areas, cultural and architectural protection areas, planned special land and other spatial areas, and the scope and volume of the remaining potentially exploitable underground space [49]. This study calculates the effective development capacity of potentially exploitable underground space based on a suitability evaluation through critical technical and theoretical analysis $[45,50]$. The established process of capacity evaluation makes a reasoned and well-informed decision about the credibility and accuracy of the USR (Figure 9).

\section{(1) Model of USR beneath buildings}

In order to avoid interference and damage to the various existing buildings in historical and cultural cities, especially to the stability of the foundation of historical buildings, construction activities in the underground space within a certain range around them need to be avoided. The size of this limited construction scope space is related to factors such as the height of the ground building, the area of the base, the shape of the foundation, and the underground geological structure (Table 6). The depth and scope of the influence of the building foundation can be determined according to the buried depth and the stability of the foundation. Therefore, the underground space under the foundation of existing buildings on the ground can be divided into three areas (Figure 10). 
(1) Area I is the affected area of the superimposed stress caused by building loads, and the affecting depth is $H=1.5 b-3 b$. The construction of the underground space in Area I must be strictly prohibited.

(2) Area II is the affected area of foundation stability caused by shear stress, and the construction of underground space requires specific engineering measures to relieve the shear stress. The USR in Area II must be controlled.

(3) Area III has fewer effects on the stability of the building foundation, which is suitable for the development of underground spaces. Area III is the reservation area of the USR.

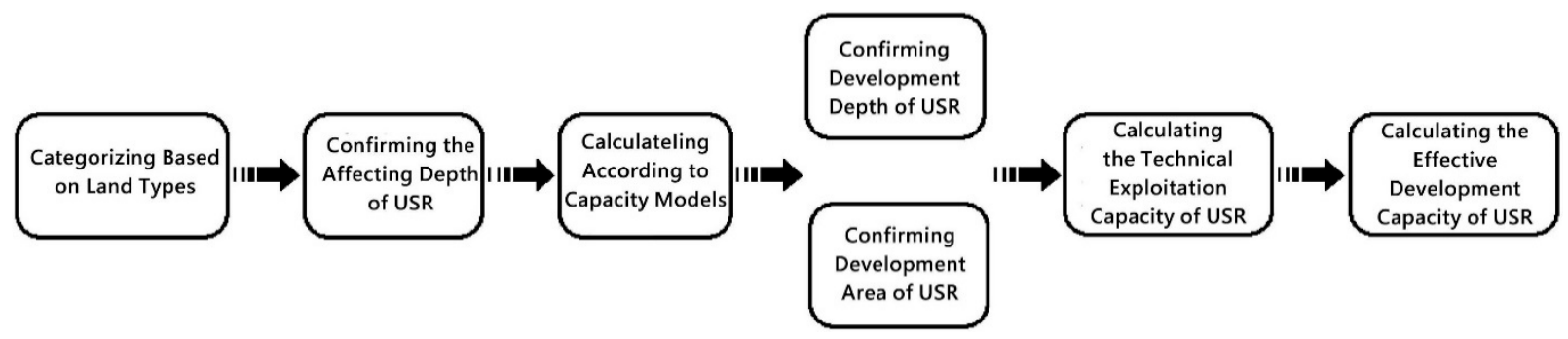

Figure 9. Process of capacity evaluation of USR.

Table 6. Affecting the depth of the building foundation.

\begin{tabular}{ccc}
\hline Types & Building Height $(\mathbf{m})$ & Affecting Depth $(\mathbf{m})$ \\
\hline Low-rise buildings & $\leq 9$ & 10 \\
Mid-rise buildings & $9 \sim 30$ & 30 \\
High-rise buildings & $\geq 30$ & $50 \sim 100$ \\
\hline
\end{tabular}

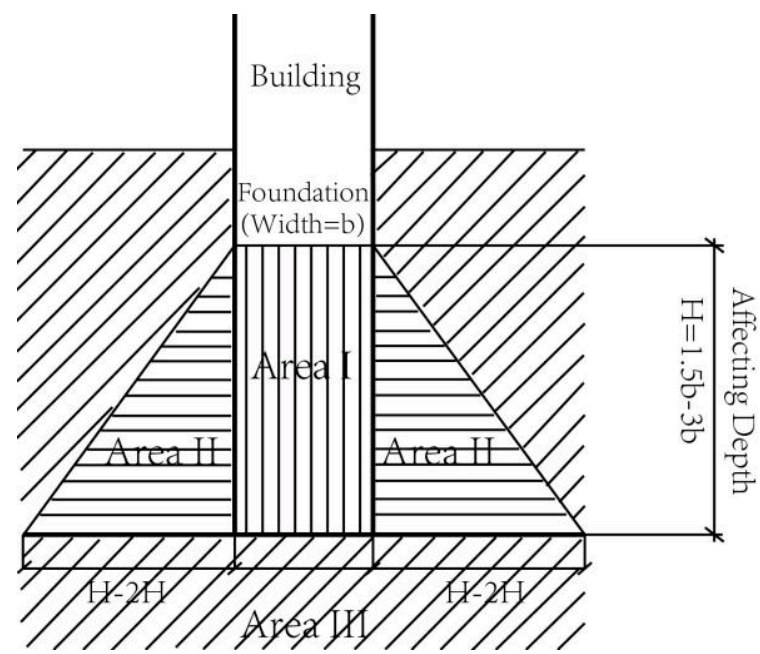

Figure 10. Zoning diagram of building foundation influence.

(2) Model of USR beneath streets and squares

The utilised types of underground spaces beneath urban streets utilise underground rapid transit, underground motorways, underground pedestrians, and underground utility corridors. Using numerical simulation analysis, some researchers have concluded that the depth of the street structure affecting underground space development is approximately $3 \mathrm{~m}$. Accordingly, the capacity evaluation model of the USR beneath the urban roads is $V_{1}$ $=(h-3) \times S$ (it is assumed that the capacity is $V$, the study area is $S$, and the investigated depth is $h$ ). The same model can be used for urban squares. Considering the bearing load of the square structure, the affecting depth can be appropriately reduced to $1 \mathrm{~m}$, and its model is $V_{2}=(h-2) \times S$. However, the influence of municipal pipelines under 
urban roads on underground space and of the greening land beside roads is ignored in the calculation model. This is because, from the current concept of intensive development, if the underground space is developed under the urban road, the comprehensive pipe gallery transformation of the original municipal pipeline is encouraged.

\section{(3) Model of USR beneath green space}

In a comprehensive study of root diameter and length by soil depth for tree species yielding a total of 123 vertical root distributions, Gale and Grigal (1987) found that the roots within $1.2 \mathrm{~m}$ of the surface soil retained over $92 \%$ root biomass and functioning, and that temperate coniferous forests showed the deepest roots [51]. Therefore, the affecting depth of USR for urban forestland is based on the equation: $H=1.70 \mathrm{~m}$ (tree roots layer) $+0.30 \mathrm{~m}$ (drainage layer of soil) $+1.00 \mathrm{~m}$ (construction buffer layer).

A great deal of previous research into the vertical root distributions of grasses and shrubs has reported that the globally averaged root distribution for all ecosystems is approximately 30\%,50\%, and 75\% for roots in the top 10, 20, and $40 \mathrm{~cm}$ of soil, respectively [52]. The rooting depth in all ecosystems of more than $40 \mathrm{~cm}$ had fewer adverse effects on root biomass and root functioning. Thus, the affecting depth of USR for urban grassland can be shown as $H=0.5 \mathrm{~m}$ (grasses roots layer) $+0.30 \mathrm{~m}$ (drainage layer of soil) $+1.00 \mathrm{~m}$ (construction buffer layer).

Protective green buffers refer to land areas with fields or parks around a town or city where construction activities are proscribed. The main purpose of the protective green buffer land is to protect the lands around larger urban centres from urban sprawl, maintain the designated area for forestry and agriculture, and provide habitats for wildlife. Accordingly, underground space development within $10 \mathrm{~m}$ below the surface must be severely restricted, helping to combat a number of soil environmental problems.

Given the three affecting depths of urban green space (Table 7), the capacity evaluation model of the USR beneath the urban green space is $V_{3}=(h-H) \times S$.

Table 7. Affecting the depth of urban green space.

\begin{tabular}{cccc}
\hline & Forestland & Grassland & Green Belt \\
\hline Roots layer $(\mathrm{m})$ & 1.70 & 0.5 & $2.00 \sim 5.00$ \\
Drainage layer $(\mathrm{m})$ & 0.30 & 0.3 & 0.8 \\
Buffer layer $(\mathrm{m})$ & 1.00 & 1.00 & 4.00 \\
Affecting depth $(\mathrm{m})$ & 3.00 & 0.80 & 10.00 \\
\hline
\end{tabular}

\section{(4) Model of USR beneath waters}

Urban waters significantly accumulate in cities, such as lakes, ponds, wetlands, rivers, and canals, which play a significant role in urban landscapes, ecosystems, and cultural heritage. The USR beneath urban waters are considered inadequate for large-scale construction, except for small-scale underground space development and utilisation. In practical terms, underground space construction of this type is of two forms: one is the traffic tunnels crossing waters, which can effectively improve the traffic network accessibility; the other is the municipal pipeline with proven technologies that allow for little negative impact on the water and environment.

Owing to the loading and permeability of the water body, a waterproof layer needs to be set for underwater space construction so that it remains relatively unaffected by water or resists the ingress of water under specified conditions. The depth from the first water-proof layer to the bottom of the water body can be considered the affected area of the USR. As a result, it is assumed that the average affecting depth of the USR beneath urban waters is $10 \mathrm{~m}$, and the capacity evaluation model can be expressed as $V_{4}=(h-10) \times S$. 
(5) Impact of the built underground space

The existing underground space is necessary to maintain the stability of the surrounding rock and soil. To ensure the structural stability and safety of the existing underground space, a reasonable safety buffer distance must be maintained between the developing underground space and the existing underground space. The USR model for the existing underground space is $V_{5}=v_{e} \times p_{e}$. Here, $v_{e}$ represents the urban theoretical potential of the USR in the existing underground space area. The $p_{e}$ represents the affecting auxiliary coefficient of the USR, which ranges from 1.2 to 3.0, according to specific geological conditions and geotechnical properties.

\section{(6) Other models of USR}

In addition to the above, other types of land use, such as external transport land, industrial land, and storage land, need to be considered in the capacity evaluation process. For the underground space development beneath these lands, the models of USR capacity evaluation in the previous study can be used as a reference.

Together, these capacity evaluation models of the USR provide important insights into establishing a scientific and objective prediction of urban underground space development. By investigating and analysing the classification, characteristics, and distribution of USR in historical and cultural cities, the USR evaluation system can not only regulate the development and utilisation of underground space, but also provide an opportunity to coordinate the development between natural resources and historical context.

\subsection{Scale Forecast}

\subsubsection{Underground Space Demand}

The demand for underground space mainly depends on many factors, such as urban development scale, socio-economic development level, urban spatial layout, people's activity mode, information and other scientific and technological levels, natural geographical conditions, laws, regulations and policies. It is an important basic parameter and planning basis in urban underground space planning. According to the function, underground space is divided into underground public space and underground non-public space; public space can be divided further into traffic space and non-traffic space [53,54]. Non-traffic spaces mainly include municipal, commercial, office, cultural, and entertainment, spaces, among others. Owing to its peculiarity, municipal underground space was not considered in this underground space demand analysis. The analysed aspects are summarised in Table 8 .

Table 8. Classification of underground space demand.

\begin{tabular}{|c|c|c|}
\hline \multicolumn{2}{|c|}{ Public Space Demand } & Non-Public Space Demand \\
\hline Non-traffic space & Traffic space & \\
\hline $\begin{array}{l}\text { Business, office, culture, } \\
\text { entertainment, etc. }\end{array}$ & $\begin{array}{c}\text { Underground parking, } \\
\text { underground expressway, } \\
\text { underground crossing street, } \\
\text { subway, etc. }\end{array}$ & Mainly auxiliary construction \\
\hline
\end{tabular}

Different areas of the city have different requirements for underground space. At the same time, the functional requirements of the units in the area for underground space are also different. This is mainly manifested in the different locations and levels of different areas and regional units in the city, and the different demands of ground functions on underground space functions. This research is based on the location level and combined with the ground function to carry out the demand assessment classification of the demand for underground space, which is mainly divided into the demand for the underground space of the building space and the underground space of the open space.

Underground space is an integral part of urban space, and urban underground space demand is a part of the whole urban space demand. Therefore, predicting the demand 
for underground space cannot be separated from the demand for the entire urban space. Chen Zhilong and others made exploratory analyses on more than 20 factors affecting underground space demand through the factor analysis method. Finally, they obtained five main factors related to underground space demand [53]. On this basis, combined with the development status of Yangzhou City, this study reclassified them into four main factors, namely location, land use nature, ground construction intensity, and underground space status. These influencing factors are represented by $\mathrm{y}_{1}, \mathrm{y}_{2}, \mathrm{y}_{3}$, and $\mathrm{y}_{4}$. The demand function is as follows:

$$
\phi=\sum_{\mathrm{i}=1}^{\mathrm{n}} \mathrm{h}_{\mathrm{i}}\left(\mathrm{y}_{1}, \mathrm{y}_{2}, \mathrm{y}_{3}, \mathrm{y}_{4}\right)
$$

where $\mathrm{n}$ is the total number of plots in the analysis area.

Under the condition of fully considering the intensity of ground construction according to the planning and current situation, carrying out a multi-level analysis on the four elements, and determining the demand by using the comprehensive prediction method.This method combines expert scoring, reference analogy and dynamic balance [53]. Firstly, according to the planned location of each plot and the nature of planned land use, the demand for underground space in Yangzhou is divided into eight levels, which decreases with the reduction of the demand location level. On this basis, combined with the demand intensity per square kilometer of Yangzhou City proposed by Chen Zhilong and others in 2007, referring to the actual demand of domestic relevant urban underground space development and planning, and according to the current overall planning of Yangzhou City, the corresponding demand intensity of each level is preliminarily determined by referring to analogy and expert scoring method (Table 9) [53]; Then, according to the principle that the higher the ground development intensity is, the stronger the demand for underground space of the plot is, the dynamic balance method is used to modify the demand intensity of underground space through the ground construction intensity. At the same time, the underground space demand of each plot was calculated according to the demand level of each plot and the corrected demand intensity, and the demand of each plot was added to obtain the theoretical underground space demand. Finally, corrections were made based on the current status of underground space. The current status of underground space was subtracted from the theoretical demand to obtain the actual demand for underground space.

Table 9. Underground space demand intensity.

\begin{tabular}{|c|c|c|c|c|}
\hline \multirow{2}{*}{ Demand Level } & \multicolumn{4}{|c|}{ Demand Intensity (Ten Thousand $\mathrm{m}^{2} / \mathrm{km}^{2}$ ) } \\
\hline & Zhengzhou & Dezhou & Yangzhou & Yangzhou Adjusted \\
\hline I & $10.60-12.00$ & $3.1-3.6$ & $4.5-5.0$ & $5.0-5.6$ \\
\hline II & $9.10-10.50$ & $2.5-3.0$ & $3.9-4.4$ & $4.3-4.9$ \\
\hline III & $7.60-9.00$ & $1.9-2.4$ & $3.3-3.8$ & $3.6-4.2$ \\
\hline IV & $6.10-7.50$ & $1.3-1.8$ & $2.7-3.2$ & $2.9-3.5$ \\
\hline $\mathrm{V}$ & $4.60-6.00$ & $0.7-1.2$ & $2.1-2.6$ & $2.2-2.8$ \\
\hline VI & $3.10-4.50$ & $0.1-0.6$ & $1.5-2.0$ & $1.5-2.1$ \\
\hline VII & $1.60-3.00$ & - & $0.9-1.4$ & $0.8-1.4$ \\
\hline VIII & $0.10-1.50$ & - & $0.1-0.8$ & $0.1-0.7$ \\
\hline
\end{tabular}

\subsubsection{Value of Underground Space}

The value of underground space is related to many factors, such as location, nature of land use, etc. [55]. In general, this can be attributed to the underground space demand of the plot and the resource quality of the plot. Among them, the resource quality is the suitability evaluation mentioned above, denoted by $\mathrm{x}, \mathrm{z}$. The value function is as follows: $\mathrm{v}=\mathrm{u}(\mathrm{x}, \mathrm{z})$. As the value of underground space is positively related to the quality and demand of underground space, the value of underground space can be expressed as a linear function of the demand and quality of underground space: $\mathrm{V}=\mathrm{XZ}$ (where $\mathrm{x}$ and $\mathrm{z}$ 
are dimensionless dimensions of demand and quality, respectively). Because the demand assessment level has eight levels and the suitability assessment level has six levels, the value assessment is obtained (Table 10).

Table 10. Value Evaluation Form.

\begin{tabular}{|c|c|}
\hline Level & Correspondence \\
\hline I & $\mathrm{X}_{1} \mathrm{Z}_{1} \mathrm{X}_{1} \mathrm{Z}_{2} \mathrm{X}_{1} \mathrm{Z}_{3} \mathrm{X}_{2} \mathrm{Z}_{1} \mathrm{X}_{3} \mathrm{Z}_{1}$ \\
\hline II & $X_{1} Z_{4} X_{1} Z_{5} X_{1} Z_{6} X_{2} Z_{2} X_{2} Z_{3} X_{3} Z_{2} X_{4} Z_{1} X_{5} Z_{1} X_{6} Z_{1}$ \\
\hline III & $\mathrm{X}_{2} \mathrm{Z}_{4} \mathrm{X}_{2} \mathrm{Z}_{5} \mathrm{X}_{3} \mathrm{Z}_{3} \mathrm{X}_{4} \mathrm{Z}_{2} \mathrm{X}_{5} \mathrm{Z}_{2} \mathrm{X}_{7} \mathrm{Z}_{1} \mathrm{X}_{8} \mathrm{Z}_{1}$ \\
\hline IV & 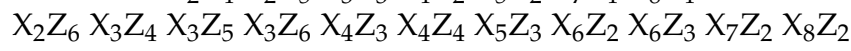 \\
\hline $\mathrm{V}$ & $\mathrm{X}_{4} \mathrm{Z}_{5} \mathrm{X}_{4} \mathrm{Z}_{6} \mathrm{X}_{5} \mathrm{Z}_{4} \mathrm{X}_{5} \mathrm{Z}_{5} \mathrm{X}_{6} \mathrm{Z}_{4} \mathrm{X}_{7} \mathrm{Z}_{3} \mathrm{X}_{7} \mathrm{Z}_{4} \mathrm{X}_{8} \mathrm{Z}_{3}$ \\
\hline VI & $\mathrm{X}_{5} \mathrm{Z}_{6} \mathrm{X}_{6} \mathrm{Z}_{5} \mathrm{X}_{6} \mathrm{Z}_{6} \mathrm{X}_{7} \mathrm{Z}_{6} \mathrm{X}_{8} \mathrm{Z}_{4} \mathrm{X}_{8} \mathrm{Z}_{5} \mathrm{X}_{8} \mathrm{Z}_{6}$ \\
\hline
\end{tabular}

\subsubsection{Planning Volume of Underground Space}

First, the planning amount of underground space in the main urban area is determined as a whole. Then the planning amount of underground space in each area is determined according to the population demand and value coefficient of underground space in each area, that is, the planning amount, so as to further control and guide each area and provide more feasible implementation for the planning. Among them, the value coefficient is the embodiment of the relative intensity of the development of the underground space in the partition, which is manifested in the ratio of the first four value levels (level I, level II, level III and level IV) of the underground space in the partition to the proportion of the total value level in the partition and its average proportion [56].

\subsubsection{Statistics and Analysis of Evaluation Results}

In this study, GIS was used to perform statistical analysis on vector data and raster data, and related distribution maps were obtained to show the evaluation results [57,58]. First, all data were digitised and standardised, and the position was defined for all digital and standardised vector data. Second, a method of combining planar element division and vertical layering was used to divide the evaluation unit. Finally, the overall result graph is formed by collecting the evaluation results of the basic unit (Figure 11).

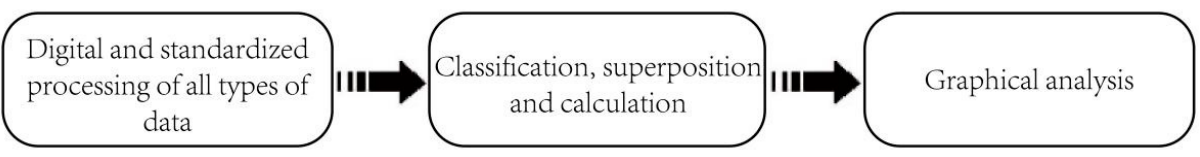

Figure 11. GIS platform use process.

\section{Results}

\subsection{Results of Suitability Evaluation}

Based on the evaluation index and model, the suitability of USR within the scope of construction land $\left(230 \mathrm{~km}^{2}\right)$ in the main urban area of Yangzhou was comprehensively evaluated by measuring the factors of quality evaluation, such as topography and hydrology, geotechnical engineering, historical and cultural context, and existing urban construction.

Regarding the calculation method above, each land block in Yangzhou City was evaluated one by one. In addition, due to the urban character of national historical and cultural cities, it was also necessary to designate some special lands as restricted construction areas for underground space development, such as historical and cultural preservation districts, unearth burial areas, historic water system preservation areas, historic mountain preservation areas, protective green buffer land, riverfront green land, and farmland.

Consequently, we obtained the "existing distribution map of USR for Yangzhou City" (Figure 12). At the same time, we revised the modified land of urban villages, commercial lands, and industrial lands. Finally, we formed the "distribution map of the evaluation level of USR in Yangzhou City" (Figure 13), according to the "Master Planning of Yangzhou City". 


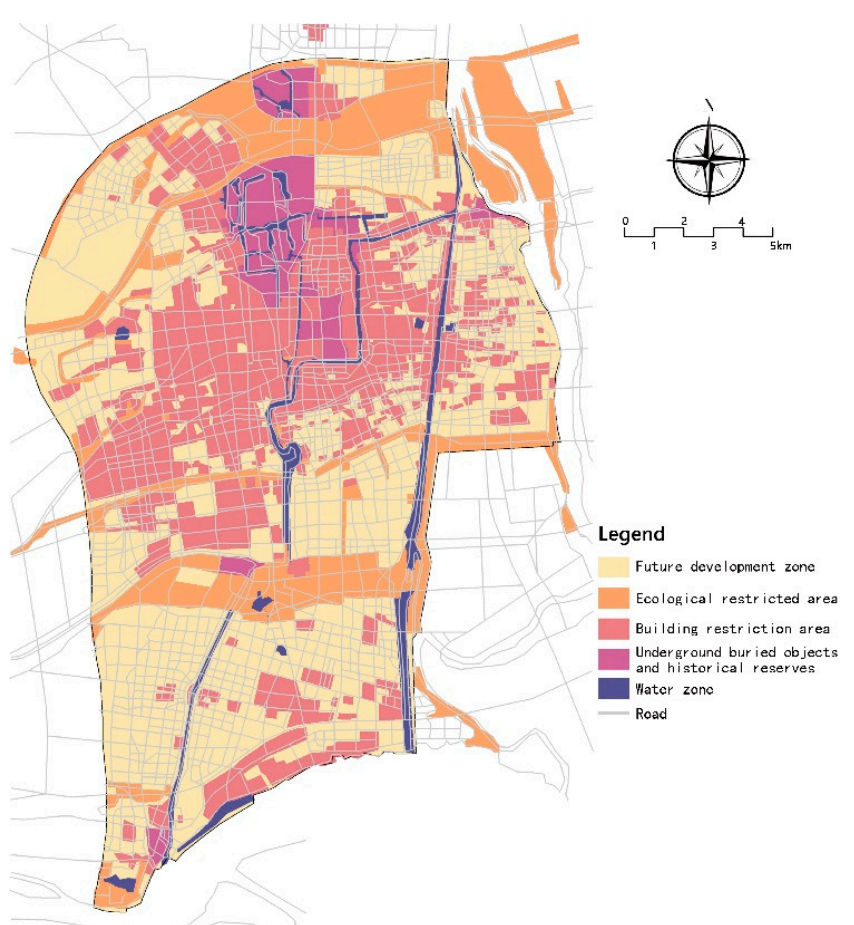

A Shallow underground space

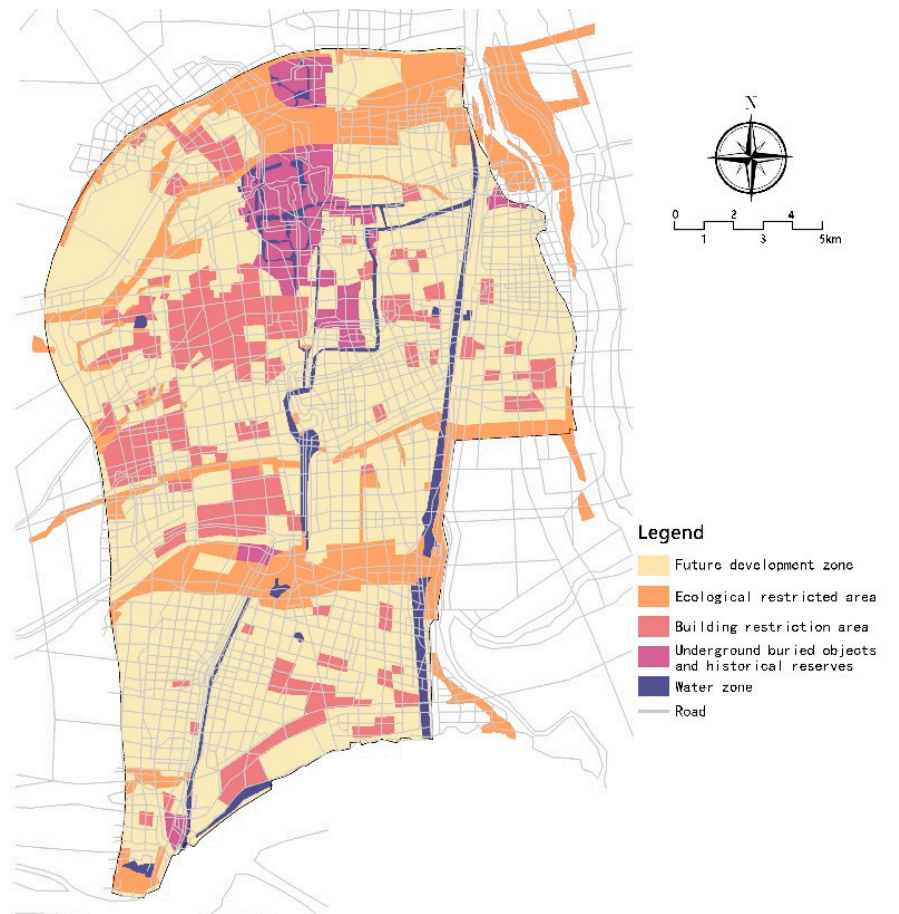

B Sub-shallow underground space

Figure 12. The Existing USR of Yangzhou city.

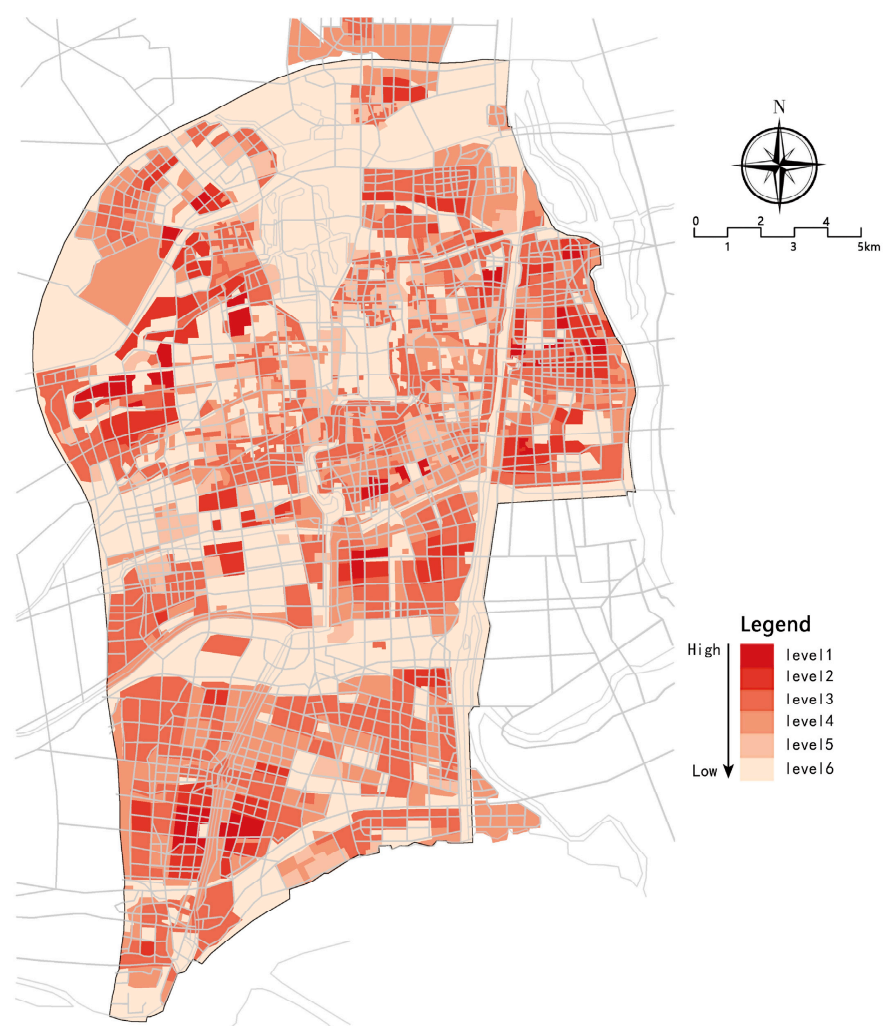

A Shallow underground space

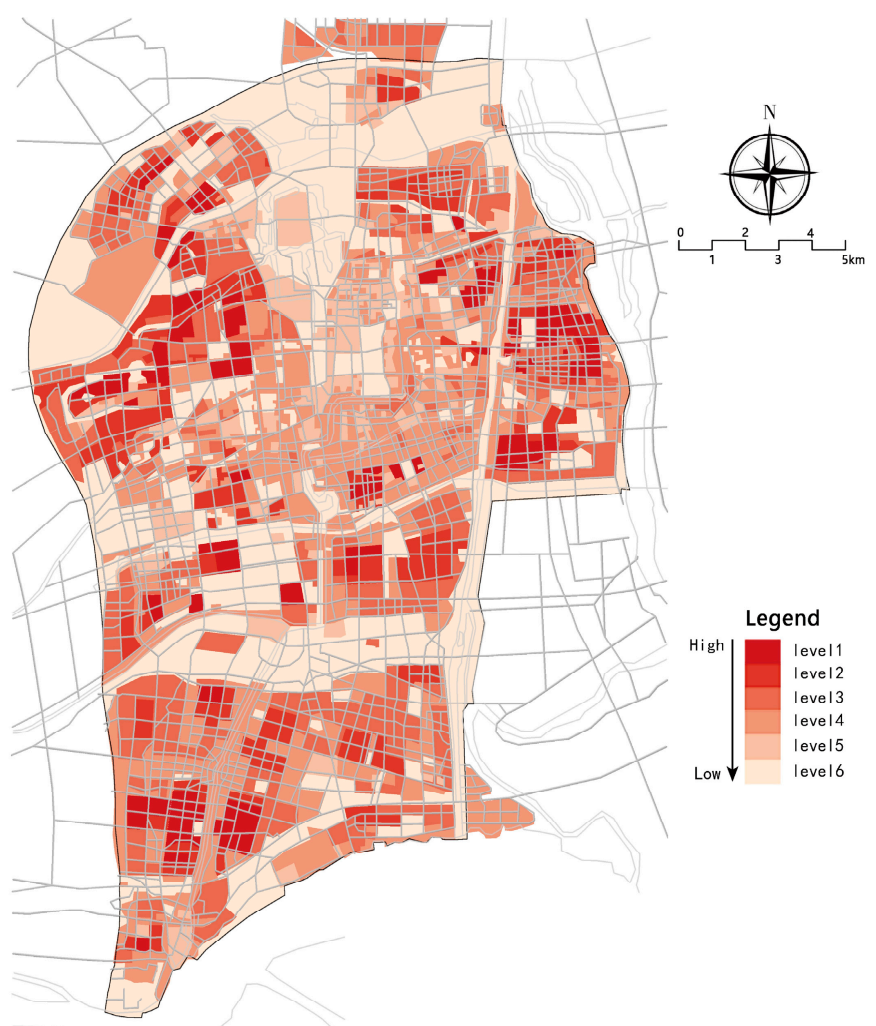

B Sub-shallow underground space

Figure 13. Evaluation results of USR in Yangzhou city. 


\subsection{Capacity Evaluation of USR for Yangzhou}

\subsubsection{Technical Exploitation Capacity of USR}

As previously indicated, in contrast to the subjective suitability measurements of urban underground space, the capacity of USR can be determined with objective performance evaluations. According to the collected data from Yangzhou City (excluding some constraints) and capacity evaluation models, Table 11 shows the capacity of USR for shallow and sub-shallow underground spaces. It is apparent from this table that the amount of USR available for technical exploitation in Yangzhou City is approximately 1.087 billion $\mathrm{m}^{3}$ in shallow underground space and 1.725 billion $\mathrm{m}^{3}$ in sub-shallow underground space.

Table 11. The technical exploitation capacity of USR for Yangzhou city.

\begin{tabular}{|c|c|c|c|c|c|}
\hline \multirow{2}{*}{$\begin{array}{l}\text { Project } \\
\text { Land Attribute }\end{array}$} & \multicolumn{2}{|c|}{ Land Area $\left(\mathrm{M} \mathrm{m}^{3}\right)$} & \multirow{2}{*}{$\begin{array}{l}\text { Shallow USR } \\
\qquad\left(\mathrm{B} \mathrm{m}^{3}\right)\end{array}$} & \multirow{2}{*}{$\begin{array}{l}\text { Sub-Shallow } \\
\text { USR }\left(\mathrm{B} \mathrm{m}^{3}\right)\end{array}$} & \multirow{2}{*}{ Details } \\
\hline & Existing & Planned & & & \\
\hline Residential land & 3660 & 940 & 3.86 & 5.49 & $\begin{array}{c}\text { The average depth of impact is } 15 \mathrm{~m} \text {, } \\
\text { and its building density is } 30 \% \text {; about } \\
60 \% \text { of the remaining } 70 \% \text { can be } \\
\text { used for underground } \\
\text { space development }\end{array}$ \\
\hline $\begin{array}{l}\text { Administration and } \\
\text { public services land }\end{array}$ & 1350 & 137 & 1.12 & 1.66 & $\begin{array}{l}\text { The average depth of impact is over } \\
20 \mathrm{~m} \text {, and its building density is } 40 \% \text {; } \\
\text { about } 50 \% \text { of the remaining } 60 \% \text { for } \\
\text { underground space development }\end{array}$ \\
\hline Municipal utilities land & 324 & 141 & 0.26 & 0.49 & $\begin{array}{l}\text { The average depth of impact is } 10 \mathrm{~m} \text {, } \\
\text { then half of the constructed land can } \\
\text { be developed }\end{array}$ \\
\hline Street and square land & 1500 & 898 & 1.85 & 2.25 & $\begin{array}{l}\text { The average depth of impact is } 3 \mathrm{~m} \text {, } \\
\text { then } 70 \% \text { of the constructed land can } \\
\text { be developed }\end{array}$ \\
\hline Transportation land & 450 & 170 & 0.17 & 0.68 & $\begin{array}{l}\text { The average depth of impact is } 3 \mathrm{~m} \text {, } \\
\text { then } 50 \% \text { of the constructed land can } \\
\text { be developed }\end{array}$ \\
\hline Industry land & 2740 & 290 & 3.13 & 4.11 & $\begin{array}{l}\text { The average depth of impact is } 10 \mathrm{~m} \text {, } \\
\text { assuming that the industrial building } \\
\text { density is } 25 \% \text {, then } 65 \% \text { of the } \\
\text { remaining } 75 \% \text { can be developed }\end{array}$ \\
\hline $\begin{array}{c}\text { Logistics and } \\
\text { warehouse land }\end{array}$ & 310 & 65 & 0.34 & 0.47 & $\begin{array}{c}\text { The average depth of impact is } 10 \mathrm{~m} \text {, } \\
\text { building density is } 35 \% \text {, and about } \\
50 \% \text { of the remaining } 65 \% \text { can be } \\
\text { used for underground } \\
\text { space development }\end{array}$ \\
\hline Green land & 1410 & 650 & 0.15 & 2.12 & $\begin{array}{c}\text { The average depth of impact is } 3 \mathrm{~m} \text {, } \\
\text { then the green land is partially } \\
\text { developed, and } 35 \% \text { of it can } \\
\text { be developed }\end{array}$ \\
\hline Special land & 56 & 9 & & & Special land cannot be developed. \\
\hline Water area & & & & & $\begin{array}{c}\text { The average depth of impact is } 10 \mathrm{~m} \text {, } \\
\text { and the partial development of the } \\
\text { water area is not accounted }\end{array}$ \\
\hline Total & 11,800 & 3300 & 10.88 & 17.27 & \\
\hline
\end{tabular}




\subsubsection{Effective Development Capacity of USR}

In practice, it is extremely difficult to develop deep underground space $(\geq 30 \mathrm{~m})$ due to the limitations of current construction engineering technology. Therefore, shallow underground space $(0--15 \mathrm{~m})$ and sub-shallow underground space $(-15--30 \mathrm{~m})$ will be utilised in the future development of Yangzhou City. Prior research and practices showed that $40 \%$ of the product of urban land area and developmental depth is the reasonable development capacity of USR [32,33], such that the formula can be represented by $V=A \times H \times 40 \%$ (" $V$ " is the capacity of USR, $A$ is the land area; " $H$ " is development depth).

Based on the comprehensive appraisal grades of suitability for each land, the specific calculation process for the effective development capacity of USR needs to adopt different development intensities at different depths, taking into account relevant factors, such as construction cost, maintenance, and safety. The adjustable ratio of different appraisal grades on shallow USR and sub-shallow USR confirmed by the Delphi method (also known as Estimate-Talk-Estimate), which relies on a panel of experts in underground space planning, is presented in Table 12. The effective developmental capacity of the USR obtained by this method can generally be controlled within the range of $20-40 \%$ of the reasonable development capacity of the USR. In accordance with the urban ground density in the main urban area of Yangzhou, the capacity value is within a reasonable range.

Table 12. Effective development capacity of USR calculation.

\begin{tabular}{|c|c|c|c|c|c|c|c|c|}
\hline \multirow{2}{*}{$\begin{array}{c}\text { Effective } \\
\text { Development }\end{array}$} & \multirow{2}{*}{\multicolumn{2}{|c|}{ Appraisal Grades }} & \multirow{2}{*}{$\begin{array}{l}\text { Technical } \\
\text { Exploitation }\end{array}$} & \multicolumn{2}{|c|}{ Shallow USR } & \multicolumn{2}{|c|}{ Sub-Shallow USR } & \multirow{2}{*}{ Ratio } \\
\hline & & & & Ratio & Capacity & Ratio & Capacity & \\
\hline \multirow{6}{*}{$V_{\mathrm{t}}$} & I & $V_{\mathrm{I}} / V_{\mathrm{t}}$ & $V_{\mathrm{I}}$ & 0.70 & $0.7 V_{\mathrm{I}}$ & 0.50 & $0.5 V_{\mathrm{I}}$ & \multirow{6}{*}{$\begin{array}{c}V_{\mathrm{e}} / V_{\mathrm{t}} \\
(20 \sim 40 \%)\end{array}$} \\
\hline & II & $V_{\mathrm{II}} / V_{\mathrm{t}}$ & $V_{\text {II }}$ & 0.50 & $0.5 V_{\mathrm{II}}$ & 0.30 & $0.3 V_{\mathrm{II}}$ & \\
\hline & III & $V_{\mathrm{III}} / V_{\mathrm{t}}$ & $V_{\text {II }}$ & 0.30 & $0.3 V_{\mathrm{III}}$ & 0.10 & $0.1 V_{\mathrm{III}}$ & \\
\hline & IV & $V_{\text {IV }} / V_{\mathrm{t}}$ & $V_{\text {IV }}$ & 0.10 & $0.1 V_{\mathrm{IV}}$ & 0.05 & $0.05 V_{\mathrm{IV}}$ & \\
\hline & $\mathrm{V}$ & $V_{\mathrm{V}} / V_{\mathrm{t}}$ & $V_{\mathrm{V}}$ & 0.05 & $0.05 V_{\mathrm{IV}}$ & 0.03 & $0.03 V_{\mathrm{IV}}$ & \\
\hline & VI & $V_{\mathrm{VI}} / V_{\mathrm{t}}$ & $V_{\mathrm{VI}}$ & 0.03 & $0.03 V_{\mathrm{VI}}$ & 0.01 & $0.01 V_{\mathrm{VI}}$ & \\
\hline \multicolumn{4}{|c|}{ Total } & \multicolumn{2}{|c|}{ Shallow USR $V_{\mathrm{e}}$} & \multicolumn{2}{|c|}{ Sub-shallow USR $V_{\mathrm{e}}$} & \\
\hline
\end{tabular}

Shallow USR $V_{\mathrm{e}}=0.7 V_{\mathrm{I}}+0.5 V_{\mathrm{II}}+0.3 V_{\mathrm{III}}+0.1 V_{\mathrm{IV}}+0.05 V_{\mathrm{IV}}+0.03 V_{\mathrm{VI}}$

Sub-shallow USR $V_{\mathrm{e}}=0.5 V_{\mathrm{I}}+.0 .3 V_{\mathrm{II}}+0.1 V_{\mathrm{III}}+0.05 V_{\mathrm{IV}}+0.03 V_{\mathrm{IV}}+0.01 V_{\mathrm{VI}}$

The results of the correlational calculation showed that the total effective development capacity of Yangzhou City is 2.2989 billion $\mathrm{m}^{3}$, of which the shallow USR are 1.0704 billion $\mathrm{m}^{3}$ and the sub-shallow USR are 1.2285 billion $\mathrm{m}^{3}$ (Table 13, Figure 14), with the deep USR reserved as a potential resource for future underground space development. Taken together, these results suggest that approximately 45.98 million $\mathrm{m}^{2}$ construction area of underground space can be planned for the future urban development of Yangzhou based on the $5 \mathrm{~m}$ story height of underground space.

Table 13. Effective development capacity of USR for Yangzhou city.

\begin{tabular}{|c|c|c|c|c|c|c|}
\hline \multirow[b]{2}{*}{ Appraisal Grades } & \multicolumn{3}{|c|}{ Shallow USR $\left(\mathrm{Bn} \mathrm{m}^{3}\right)$} & \multicolumn{3}{|c|}{ Sub-Shallow USR $\left(\mathrm{Bn} \mathrm{\textrm {m } ^ { 3 } )}\right.$} \\
\hline & $\begin{array}{c}\text { Technical } \\
\text { Exploitation }\end{array}$ & Ratio & $\begin{array}{c}\text { Effective } \\
\text { Development }\end{array}$ & $\begin{array}{c}\text { Technical } \\
\text { Exploitation }\end{array}$ & Ratio & $\begin{array}{c}\text { Effective } \\
\text { Development }\end{array}$ \\
\hline I & 0.4185 & 0.70 & 0.2929 & 1.0523 & 0.50 & 0.5261 \\
\hline II & 0.6685 & 0.50 & 0.3343 & 1.5680 & 0.30 & 0.4704 \\
\hline III & 1.0903 & 0.30 & 0.3271 & 1.5094 & 0.10 & 0.1509 \\
\hline IV & 0.5892 & 0.10 & 0.0589 & 1.2248 & 0.05 & 0.0612 \\
\hline $\mathrm{V}$ & 0.8794 & 0.05 & 0.0440 & 0.4313 & 0.03 & 0.0129 \\
\hline VI & 0.4413 & 0.03 & 0.0132 & 0.7004 & 0.01 & 0.0070 \\
\hline Total & 4.0872 & - & 1.0704 & 6.4862 & - & 1.2285 \\
\hline
\end{tabular}



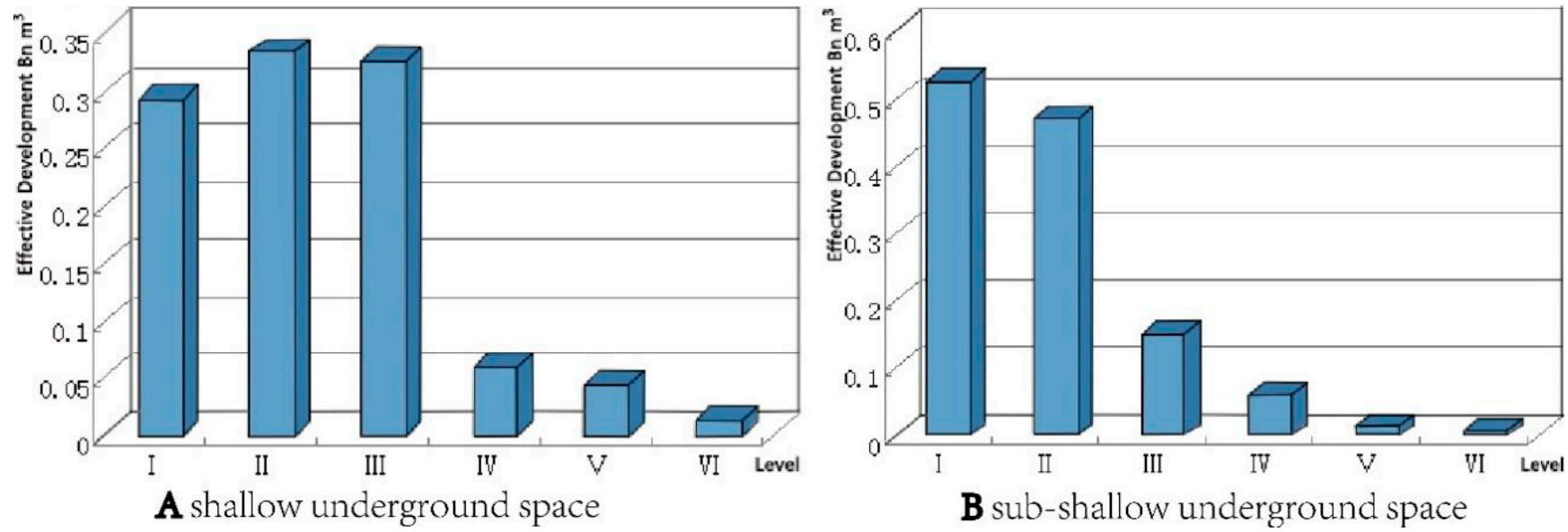

Figure 14. Distribution of effective development capacity of USR for Yangzhou city ((A) is shallow underground space and (B) is sub-shallow underground space).

\subsection{Scale Forecast}

\subsubsection{Demand Forecast}

(1) Requirement of underground space in the building space

Because the same land use is in the same demand location, the underground space demand level is the same; the same land use property is in different demand locations, and the underground space demand level differs. The underground space demand level decreases gradually as the demand location level decreases. Within the same demand location range, the level of underground space requirements varies in principle with the nature of the land. Therefore, this study comprehensively considers the location, function, nature, structure, and layout of the districts in the overall planning of Yangzhou City. The different properties of the main urban area of Yangzhou City are obtained according to the importance of the role of different land use properties in the main urban area. The demand for underground space in planning land and the level of demand for underground spaces in the building space (Figure 15A,B). It is worth noting that it takes into account the special use of urban land, water area, prohibited construction area, restricted construction area, cultural relic protection area, etc. Due to particularities of nature and jurisdiction, the demand for underground space in the corresponding plot is not being considered for the time being.

Based on the determination of the demand level, the demand model was used to calculate the demand for underground space. The determination of demand must be compatible with the city's economic development level, population growth rate, per capita GDP, output per unit area, and other urban development indicators. Plots of different demand levels correspond to different demand intensities. The higher the demand level, the greater the demand intensity. At the same time, the demand intensity of underground space is related to the intensity of the ground construction of the corresponding plot. The higher the intensity of ground development, the stronger the demand for underground space in the plot. Therefore, combined with the comprehensive indicators of urban development, such as the urban development scale and economic strength of Yangzhou, and the general plan for the construction intensity of the main urban area referring to the actual development and planning of the relevant urban underground space in China, the comprehensive prediction method and correction of the corresponding underground space demand intensity and the underground space demand of the urban land planned for the main urban area quantitative analysis show that the theoretical demand for underground space in the main urban area is 239.69-2.927 million $\mathrm{m}^{2}$ (Figure 15C,D). 
A Location division of underground space demand in main urban areas

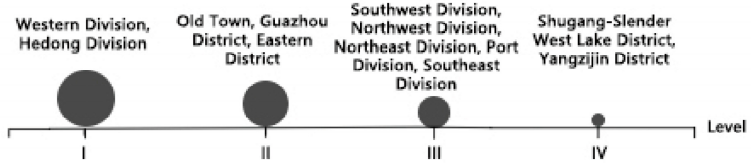

B Classification of underground space requirements in main urban areas
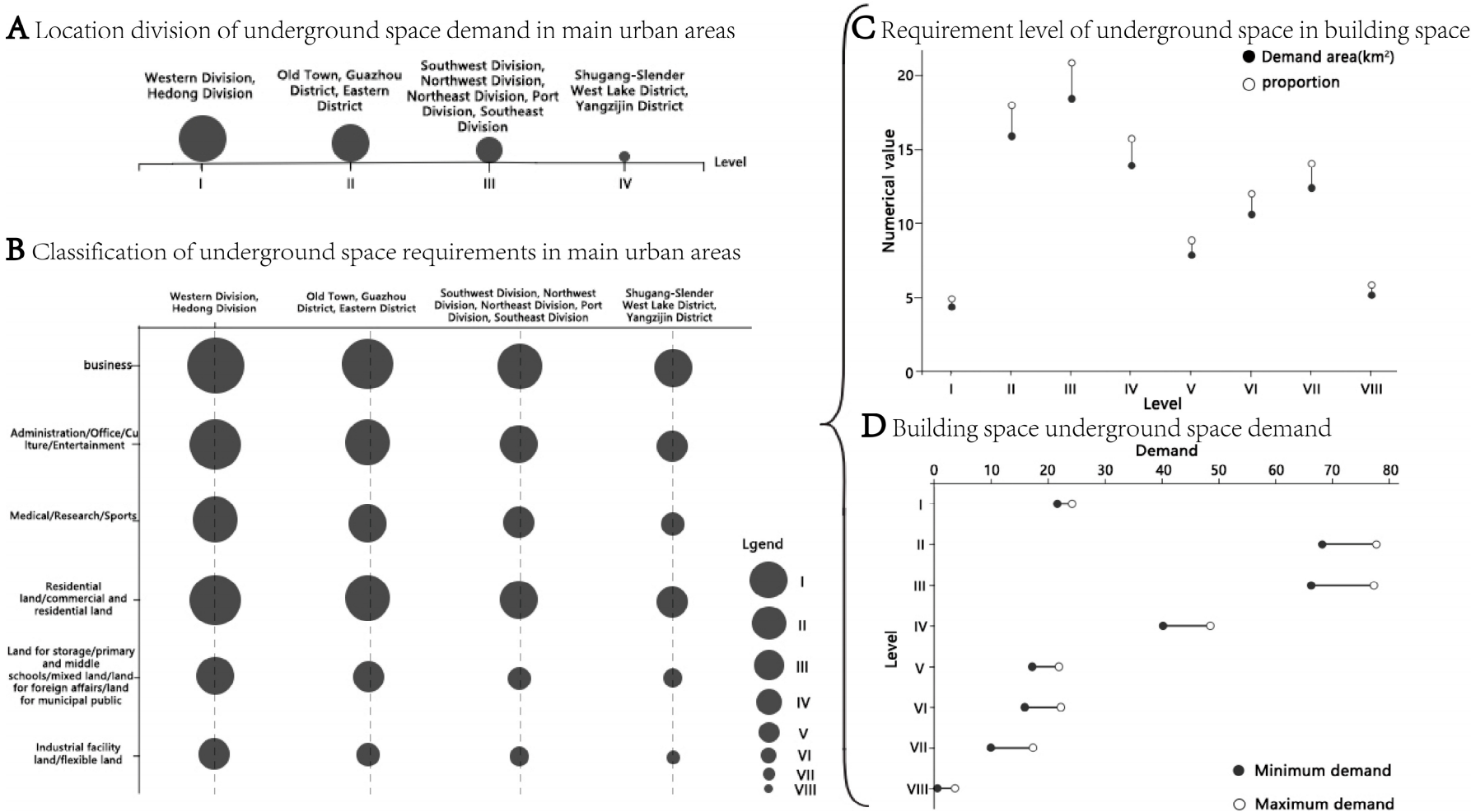

Figure 15. Underground space requirements of building space.

(2) Open space underground space requirements

According to the determination of the demand level, the actual demand analysis, and comprehensive prediction method of the underground space demand intensity, the underground space demand of different open spaces in the main urban area was obtained (Table 14).

Table 14. Underground space demand of open space.

\begin{tabular}{|c|c|c|c|c|}
\hline \multicolumn{2}{|c|}{ Category } & \multirow{3}{*}{$\begin{array}{c}\text { Area }\left(\mathbf{k m}^{\mathbf{2}}\right) \\
13.0 \\
1.1\end{array}$} & \multirow{3}{*}{$\begin{array}{c}\begin{array}{c}\text { Demand } \\
\text { (Ten Thousand } \mathbf{m}^{2} \text { ) }\end{array} \\
10-15\end{array}$} & \multirow{3}{*}{$\begin{array}{c}\text { Remarks } \\
\text { Civil defense }\end{array}$} \\
\hline Greening & Public lawn & & & \\
\hline Greents & Other green areas & & & \\
\hline \multicolumn{2}{|c|}{ Roads, squares } & 15.0 & $15-30$ & $\begin{array}{l}\text { Including civil defense } \\
\text { and pedestrian access }\end{array}$ \\
\hline \multicolumn{2}{|c|}{ Special land and non-urban construction land } & 134.56 & - & \\
\hline \multicolumn{2}{|c|}{ total } & 163.66 & $25-45$ & \\
\hline
\end{tabular}

(3) Underground space demand in the main urban area

Based on the above calculation of the underground space demand of building space and open space, the underground space demand scale of the main urban area was determined to be 2.6469-3.377 million $\mathrm{m}^{2}$. At the same time, according to the survey, the existing underground space (including civil defence engineering) in the main urban area of Yangzhou is $564,700 \mathrm{~m}^{2}$. According to the current situation, the demand for underground space is corrected, and the actual demand for underground space is approximately 2.0822-2.8123 million $\mathrm{m}^{2}$ (including civil defence engineering). 


\subsubsection{Value of Underground Space}

The suitability of the shallow underground space in the main urban area was analysed. The open underground space in the main urban area was considered an elastic demand and was not corrected and evaluated in the value evaluation. The preliminary value analysis of the underground space in the main urban area was carried out based on the requirements and suitability assessment results mentioned above. The area of the value area was calculated. The value analysis was further corrected by combining the evaluation levels of urban development comprehensive indicators such as the distribution of land prices in the main urban area of Yangzhou, real estate prices, urban development scale, and economic strength, to obtain the value areas at all levels (Figure 16).

A Correction chart of value grade of underground space in main urban area
B Correction statistics of the area of different value levels of underground space in the main urban area

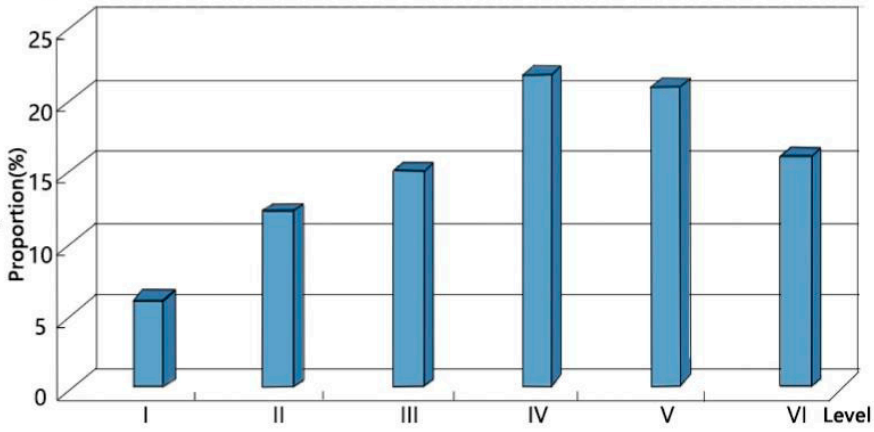

C Correction statistics on the proportion of different value levels of underground space in the main urban area

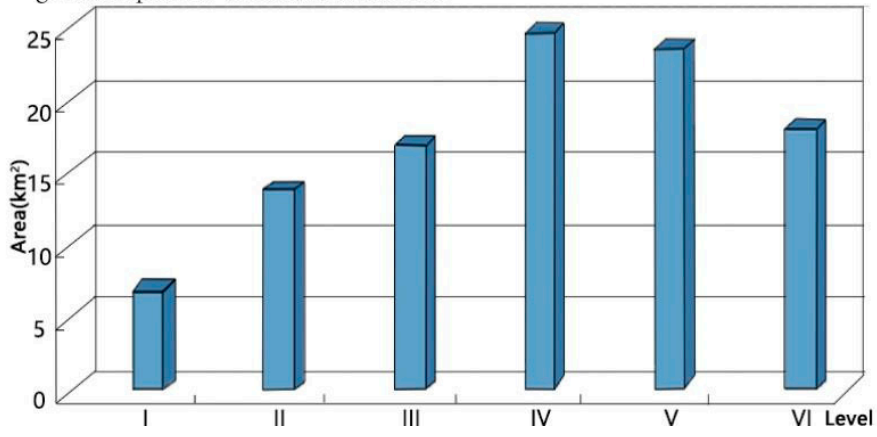

Figure 16. The value grade correction map of the underground space in the main urban area and the area and proportion value.

Based on the expert system experience summarised by the research centre with reference to many urban underground space statuses and planning, the value intensity of the underground space in the main urban area was assigned. The value of the underground space in the main urban building space was calculated to be approximately 1.713-2.4197 million $\mathrm{m}^{2}$ (Figure 17).

According to the previous analysis, the open space underground space demand in the main urban area is elastic demand, and its underground development scale is $200,000-450,000 \mathrm{~m}^{2}$. Combined with the evaluation and correction of the underground space value of the building space, the theoretical value of the underground space in the main urban area is 1.963-2.8697 million $\mathrm{m}^{2}$. The current survey found that the existing underground space in the main urban area was $564,700 \mathrm{~m}^{2}$. On this basis, the actual underground space value of the main urban area was 1.3983-2.305 million $\mathrm{m}^{2}$. 

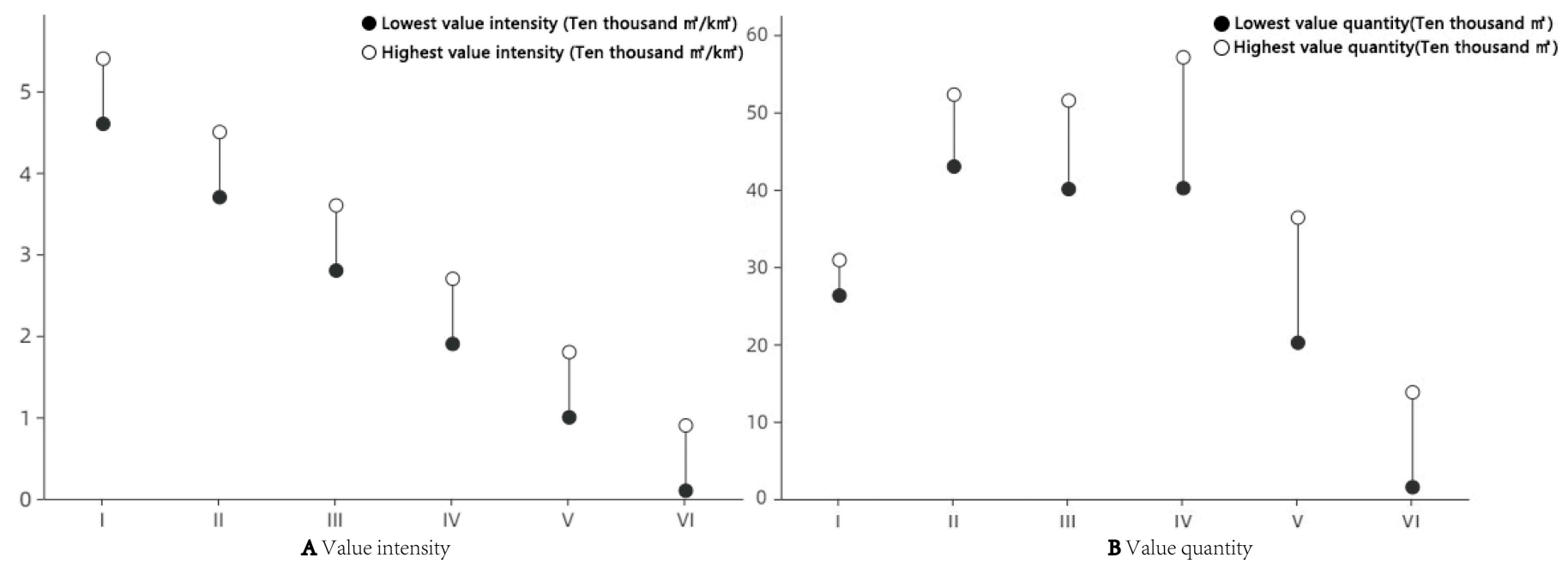

Figure 17. The value intensity of underground space and the value of underground space in the main urban area.

\subsubsection{Planning Volume of Underground Space}

(1) Determination of the planned amount of underground space in the main urban area

Through the demand and value analysis of the underground space in the main urban area, we determined that the underground space planning volume was within the range of 2.1-2.95 million $\mathrm{m}^{2}$. The specific planning volume was analysed from the underground space investment source, the economic strength analysis of Yangzhou City, and the underground planning volume from the perspectives of the city's economic support, the construction experience of other Chinese cities of the same level, and the current construction and development status of Yangzhou City. We determined that the planned underground space of the main urban area in this study is $2.2-2.6$ million $\mathrm{m}^{2}$.

(2) Determination of planning volume of underground space zoning

The planning volume of underground space zoning is mainly determined by the population demand and the value coefficient. The main determinants of population demand are the partition population and planning volume of the underground space per capita. Combined with the value coefficient, the theoretical planning volume of zoning can be obtained. The value coefficient is a manifestation of the relative intensity of the development of the subregional underground space. It is expressed as the ratio of the first four value levels (Level 1, Level 2, Level 3, and Level 4) of the subarea underground space to the total value level of the subarea and its average ratio (Table 15).

Table 15. Control of underground space planning volume in each district.

\begin{tabular}{cccc}
\hline Partition Name & $\begin{array}{c}\text { Planning Population } \\
\text { (Ten Thousand People) }\end{array}$ & Value Coefficient & $\begin{array}{c}\text { Zoning Planning Volume } \\
\text { (Ten Thousand Square Metres) }\end{array}$ \\
\hline old Town & 7 & 1.4 & $14.76 \sim 17.45$ \\
Eastern Division & 16 & 1.1 & $26.52 \sim 31.34$ \\
Northeast Division & 10.5 & 0.4 & $6.33 \sim 7.48$ \\
Southeast Division & 3.5 & 0.4 & $2.11 \sim 2.49$ \\
Hadong District & 16 & 2.1 & $50.38 \sim 59.48$ \\
Northwest Division & 6 & 0.4 & $3.62 \sim 4.27$ \\
West Division & 40 & 1.5 & $89.96 \sim 106.22$ \\
\hline
\end{tabular}


Table 15. Cont.

\begin{tabular}{cccc}
\hline Partition Name & $\begin{array}{c}\text { Planning Population } \\
\text { (Ten Thousand People) }\end{array}$ & Value Coefficient & $\begin{array}{c}\text { Zoning Planning Volume } \\
\text { (Ten Thousand Square Metres) }\end{array}$ \\
\hline Southwest Division & 10 & 0.4 & $6.03 \sim 7.12$ \\
Yangzijin District & 1 & 0.2 & $0.30 \sim 0.36$ \\
Guazhou District & 8 & 1.4 & $16.87 \sim 19.94$ \\
Port zone & 6 & 0.4 & $3.62 \sim 4.27$ \\
Slender West Lake District & 124 & & $220.11 \sim 259.88$ \\
total & 1 & & 2 \\
\hline
\end{tabular}

\section{Discussion}

This study aimed to evaluate the suitability of USR in historical and cultural cities, calculate the development capacity, and then predict the scale. Through in-depth comparison and systematic analysis of large samples, the most obvious discovery is that topography, hydrogeology, geotechnical engineering, historical and cultural context, as well as existing urban construction are the main factors driving the underground development space in historical cities. Then, a comprehensive evaluation framework and model in line with the principle of natural resources and the characteristics of USR are established using a combination of qualitative and quantitative methods. It is found that this combined method is sensitive and reliable. In the suitability evaluation stage, the social network analysis method, Delphi method, and interpretative structural equation model method were used to screen the indicators with more objective, logical control. A large amount of data was trained by a random forest algorithm to obtain the index weight. At the same time, the influence of USR multiple factors and inaccurate data was solved by combining the fuzzy set method. The key characteristics of subordination and inclusion of urban underground space were defined to assist the resource allocation of urban underground space in the capacity evaluation stage. On this basis, the scale of underground space in the future was predicted by a mathematical model combined with qualitative analysis.

For the development and utilisation of underground space in famous historical and cultural cities, the existing studies mostly use the analytic hierarchy process to evaluate suitability $[34,35,57]$. There is a lack of a comprehensive system framework that integrates the suitability, capacity, and scale affecting the development and utilisation of underground space. At the same time, the determination weight of the analytic hierarchy process is too subjective; it is not conducive to the rationality of determining the weight of various influencing factors of complex historical and cultural cities. Therefore, based on considering historical and cultural factors through the analysis and comparison of large samples and cases of underground space development, this study puts forward multi-layer information superposition to solve the main problems faced in the whole process of underground space development and utilisation. It is helpful to formulate effective planning policies for famous historical and cultural cities in practice and provide a sounder logical framework and method application in research. Although there is an appropriate framework for the USR evaluation modelled in this study, two limitations need to be noted. The first is that the process did not consider the connection and fusion between aboveground and underground spaces, which are the future urban development patterns. Therefore, regarding this limitation, prospective research on the relationship and interaction between aboveground and underground space in historical cities is necessary to apply USR evaluation in urban development and policy-making. Furthermore, the factors affecting USR need to be conditioned by urban above-under spatial integration characteristics, and the data and examples should be easy to collect and process.

Although the USR evaluation framework established in this study is appropriate, it also has limitations. First of all, the connection and integration of aboveground and underground spaces in the future urban development model are not considered [59]. Secondly, although the historical and cultural elements are included in the suitability evaluation, and the suitability evaluation results are used in the calculation of capacity 
and scale, the consideration of complex intertwined historical and cultural factors is still insufficient, and a more consistent method model is needed to bring it into the whole process of underground space development and utilisation. Therefore, in view of the above limitations, an important role in the practicability and operability of underground space development and utilisation of historical and cultural cities in the future is to prospectively study the relationship and interaction between aboveground space and underground space, analyse the influence mechanism of historical factors on underground space, and then revise the mathematical model to calculate the actual development capacity and planning volume.

\section{Conclusions}

Historic places create connections to our heritage that help us understand our past, appreciate our triumphs, and learn from our mistakes. Historic places help define and distinguish communities by building a strong sense of identity. The past is everywhere, and it is nowhere. Urban history may be considered the raw facts of the past in the city [60], while urban heritage is also regarded as history processed through ideology, mythology, nationalism, local pride, and romantic ideas [61]. However, modernism in urbanisation has often seemed to erase memory from the city [62], so that the urban development of national famous historical and cultural cities in China must cope with many challenges and opportunities. As capital valorisation pushes toward exhaustive exploitation of land, urban land becomes scarce. At the same time, the concept of compact cities is envisioned as a challenge. Many urban development theorists foresee the development of a third axis (Z-axis) of cities to avoid superficial and dangerous urban crises in the future. A large number of studies have described the roles of high-rise buildings and overpass bridges [63]. Even if they agree on little else, there is a consensus among urban experts that the underground dimension represents a significant epochal change in historical and cultural cities.

Under the premise of protecting the historical and cultural contexts of cities, the development and utilisation of underground spaces can substantially alleviate "urban diseases", such as environmental degradation, traffic congestion, and energy consumption [64]. This research was designed to predict how the USR will develop and estimate the effects of interventions. The established USR evaluation system of famous historical and cultural cities is the main method and necessary part of urban heritage protection and underground space development. It is conducive to urban environmental protection, improves urban management efficiency, and promotes sustainable utilisation of urban space resources. In the interdisciplinary research, the disciplines and the relationship between urban heritage protection and underground space development are discussed through qualitative interviews with experts and scholars in the field of urban development $[61,65]$. Using the fuzzy comprehensive evaluation model based on fuzzy set theory, the suitability of underground space in famous historical and cultural cities is evaluated by integrating quantitative urban underground space trends and qualitative geotechnical and geographic data. At the same time, based on the capacity model to calculate the effective development capacity of resources, using a combination of mathematical function and qualitative analysis to predict the scale of underground space provides strong support for the future development of underground space.

The sheer breadth of USR evaluation, along with its successful integration of theory and practice, can help redefine a rapidly changing urbanisation scenario of historical and cultural cities, as its firm grounding and future-looking ambit ensure that the work will be an indispensable starting point for further sustainable development [29]. The methods and models of this study have a number of important implications for the future practice of urban underground dimension development for famous national historical and cultural cities in China. 
Author Contributions: Conceptualization, Jizhong Shao, Guan Liu and Hong Yuan; methodology, Jizhong Shao, Guan Liu and Qize Song; software, Guan Liu and Qize Song; validation, Jizhong Shao, Guan Liu and Minge Yang; formal analysis, Guan Liu, Xiaosi Zhang and Yuxin Zhang; investigation, Guan Liu and Qize Song; resources, Hong Yuan, Yanran Tan and Qize Song; data curation, Dan Luo and Qize Song; writing — original draft preparation, Jizhong Shao and Guan Liu; writing-review and editing, Jizhong Shao and Guan Liu; visualization, Guan Liu; supervision, Jizhong Shao; project administration, Jizhong Shao and Guan Liu; funding acquisition, Jizhong Shao All authors have read and agreed to the published version of the manuscript.

Funding: This research was funded by the National Natural Science Foundation of China (51878339); The Fundamental Research Funds for the Central Universities (105-11042010016); Key Project of Philosophy and Social Science Research in Colleges and Universities in Jiangsu Province (2019SJZDA020); Project of the Social Science Fund of Jiangsu Province (19GLB006); Technology Research; Development Program of the Construction Department of Jiangsu Provincial (2018ZD303); and Project of Teaching Studio of Huazhong Agricultural University.

Data Availability Statement: The study did not report any data.

Acknowledgments: The authors would like to express their sincere thanks to the city council and planning departments of Yangzhou for providing data for research.

Conflicts of Interest: The authors declare no conflict of interest.

\section{Appendix A}

Table A1. First level index binarization matrix.

\begin{tabular}{|c|c|c|c|c|c|c|}
\hline Index Level 1 & $\begin{array}{l}\text { Maosheng Zhang, } \\
\text { Tonglu Li, etc. }\end{array}$ & $\begin{array}{l}\text { Ping Zhang, } \\
\text { Yu Xiao }\end{array}$ & $\begin{array}{c}\text { Kun Liu, } \\
\text { Jian Peng, etc. }\end{array}$ & $\begin{array}{c}\text { Sen Liu, } \\
\text { Zhiliang Dong }\end{array}$ & $\begin{array}{c}\text { Xingxin Liu, } \\
\text { Haiyou Peng, etc. }\end{array}$ & $\begin{array}{l}\text { Pinrui Qin, } \\
\text { Shuai Gao, etc. }\end{array}$ \\
\hline Site stability & 0 & 0 & 1 & 0 & 0 & 0 \\
\hline Current status of underground space & 0 & 1 & 1 & 0 & 0 & 0 \\
\hline Status of ground space & 0 & 0 & 1 & 0 & 0 & 0 \\
\hline $\begin{array}{l}\text { Protection and development of } \\
\text { historical cultural relics }\end{array}$ & 0 & 1 & 0 & 0 & 0 & 0 \\
\hline Spatial location conditions & 0 & 1 & 0 & 0 & 0 & 0 \\
\hline Sensitive factor & 0 & 0 & 0 & 1 & 0 & 0 \\
\hline Formation lithology & 0 & 0 & 0 & 0 & 1 & 0 \\
\hline Ground subsidence & 0 & 0 & 0 & 0 & 0 & 0 \\
\hline Rock conditions & 0 & 0 & 0 & 0 & 0 & 0 \\
\hline Bad rock and soil & 0 & 0 & 0 & 0 & 0 & 0 \\
\hline Building site category & 0 & 0 & 0 & 0 & 0 & 0 \\
\hline Sensitive factor & 0 & 0 & 0 & 0 & 0 & 0 \\
\hline City conditions & 0 & 0 & 0 & 0 & 0 & 0 \\
\hline Natural conditions & 0 & 0 & 0 & 0 & 0 & 0 \\
\hline Economic and technical conditions & 0 & 0 & 0 & 0 & 0 & 0 \\
\hline $\begin{array}{l}\text { Rock-soil body type and combination } \\
\text { characteristics }\end{array}$ & 0 & 0 & 0 & 0 & 0 & 0 \\
\hline Rock and soil characteristics & 0 & 0 & 0 & 0 & 0 & 0 \\
\hline $\begin{array}{c}\text { Impact of underground space } \\
\text { development }\end{array}$ & 0 & 0 & 0 & 0 & 0 & 0 \\
\hline Site conditions & 0 & 0 & 0 & 0 & 0 & 0 \\
\hline Cost per unit area & 0 & 0 & 0 & 0 & 0 & 0 \\
\hline $\begin{array}{l}\text { Existing facilities and various } \\
\text { protection needs }\end{array}$ & 0 & 0 & 0 & 0 & 0 & 0 \\
\hline Socioeconomic factors & 0 & 0 & 0 & 0 & 0 & 0 \\
\hline Geological structure & 1 & 0 & 0 & 1 & 1 & 0 \\
\hline Geological disaster & 1 & 0 & 0 & 0 & 0 & 0 \\
\hline Environmental geology & 0 & 0 & 0 & 0 & 0 & 1 \\
\hline Human engineering activities & 0 & 0 & 0 & 0 & 0 & 1 \\
\hline Adverse geological effects & 0 & 0 & 0 & 1 & 0 & 0 \\
\hline Soil condition & 0 & 0 & 0 & 0 & 0 & 0 \\
\hline topography & 1 & 0 & 1 & 1 & 1 & 0 \\
\hline Engineering Geology & 1 & 1 & 1 & 0 & 0 & 1 \\
\hline Hydrogeology & 1 & 1 & 1 & 1 & 1 & 1 \\
\hline
\end{tabular}


Table A2. First level index binarization matrix.

\begin{tabular}{|c|c|c|c|c|c|c|}
\hline Index Level 1 & $\begin{array}{c}\text { Zhiqiang Xie, } \\
\text { Zhengang Zhai, etc. }\end{array}$ & $\begin{array}{l}\text { Yongzhi } \\
\text { Zhang }\end{array}$ & $\begin{array}{c}\text { Jing Ye, } \\
\text { Weisheng Hou, etc. }\end{array}$ & $\begin{array}{c}\text { Ming Yang, } \\
\text { Chenghe Zhu, etc. }\end{array}$ & $\begin{array}{c}\text { Jian Liu, } \\
\text { Yongyao Wei, etc. }\end{array}$ & $\begin{array}{c}\text { Zhen Zhou, } \\
\text { Wenbo Wu, etc. }\end{array}$ \\
\hline Site stability & 0 & 1 & 0 & 0 & 0 & 0 \\
\hline Current status of underground space & 0 & 0 & 0 & 0 & 0 & 0 \\
\hline Status of ground space & 0 & 0 & 0 & 0 & 0 & 0 \\
\hline Protection and development of & 0 & 0 & 0 & 0 & 0 & 0 \\
\hline Spatial location conditions & 0 & 0 & 0 & 0 & 0 & 0 \\
\hline Sensitive factor & 0 & 0 & 0 & 0 & 0 & 0 \\
\hline Formation lithology & 0 & 0 & 0 & 0 & 0 & 0 \\
\hline Ground subsidence & 0 & 1 & 0 & 0 & 0 & 0 \\
\hline Rock conditions & 0 & 0 & 1 & 0 & 0 & 0 \\
\hline Bad rock and soil & 0 & 0 & 0 & 0 & 1 & 0 \\
\hline Building site category & 0 & 0 & 0 & 0 & 1 & 0 \\
\hline Sensitive factor & 0 & 0 & 0 & 0 & 0 & 0 \\
\hline City conditions & 0 & 0 & 0 & 0 & 0 & 0 \\
\hline Natural conditions & 0 & 0 & 0 & 0 & 0 & 0 \\
\hline Economic and technical conditions & 0 & 0 & 0 & 0 & 0 & 0 \\
\hline $\begin{array}{l}\text { Rock-soil body type and combination } \\
\text { characteristics }\end{array}$ & 0 & 0 & 0 & 0 & 0 & 0 \\
\hline Rock and soil characteristics & 0 & 0 & 0 & 0 & 0 & 0 \\
\hline $\begin{array}{c}\text { Impact of underground space } \\
\text { development }\end{array}$ & 0 & 0 & 0 & 0 & 0 & 0 \\
\hline Site conditions & 0 & 0 & 0 & 0 & 0 & 0 \\
\hline Cost per unit area & 0 & 0 & 0 & 0 & 0 & 0 \\
\hline $\begin{array}{l}\text { Existing facilities and various } \\
\text { protection needs }\end{array}$ & 0 & 0 & 0 & 0 & 0 & 0 \\
\hline Socioeconomic factors & 0 & 0 & 0 & 0 & 0 & 0 \\
\hline Geological structure & 0 & 0 & 1 & 0 & 0 & 0 \\
\hline Geological disaster & 0 & 0 & 0 & 0 & 1 & 0 \\
\hline Environmental geology & 0 & 0 & 0 & 1 & 0 & 0 \\
\hline Human engineering activities & 0 & 0 & 0 & 1 & 0 & 0 \\
\hline Adverse geological effects & 1 & 0 & 0 & 0 & 0 & 0 \\
\hline Soil condition & 1 & 0 & 1 & 0 & 0 & 0 \\
\hline topography & 1 & 1 & 0 & 0 & 1 & 0 \\
\hline Engineering Geology & 1 & 1 & 0 & 1 & 0 & 1 \\
\hline Hydrogeology & 1 & 1 & 0 & 1 & 1 & 0 \\
\hline
\end{tabular}

Table A3. First level index binarization matrix.

\begin{tabular}{|c|c|c|c|c|c|c|}
\hline Index Level 1 & $\begin{array}{l}\text { Jinxiu Lao, } \\
\text { Naiyi Wei, etc. }\end{array}$ & $\begin{array}{l}\text { Nian Ren, } \\
\text { Jiang Xiao, etc. }\end{array}$ & $\begin{array}{c}\text { Hui Tang, } \\
\text { Heng Kuang, etc. }\end{array}$ & $\begin{array}{c}\text { Hui Li, } \\
\text { Wei Shi, etc. }\end{array}$ & $\begin{array}{c}\text { Xin Tang, } \\
\text { Jian Liu, etc. }\end{array}$ & Ting Jiang \\
\hline Site stability & 1 & 0 & 0 & 0 & 1 & 0 \\
\hline Current status of underground space & 0 & 1 & 0 & 0 & 0 & 0 \\
\hline Status of ground space & 0 & 1 & 0 & 0 & 0 & 0 \\
\hline $\begin{array}{c}\text { Protection and development of historical cultural } \\
\text { relics }\end{array}$ & 0 & 1 & 0 & 1 & 0 & 0 \\
\hline Spatial location conditions & 0 & 0 & 0 & 0 & 0 & 0 \\
\hline Sensitive factor & 0 & 0 & 0 & 0 & 0 & 0 \\
\hline Formation lithology & 0 & 0 & 0 & 0 & 0 & 0 \\
\hline Ground subsidence & 1 & 0 & 0 & 0 & 0 & 0 \\
\hline Rock conditions & 0 & 0 & 0 & 0 & 0 & 1 \\
\hline Bad rock and soil & 0 & 0 & 0 & 0 & 1 & 0 \\
\hline Building site category & 0 & 0 & 0 & 0 & 0 & 0 \\
\hline Sensitive factor & 0 & 0 & 0 & 0 & 0 & 0 \\
\hline City conditions & 0 & 0 & 0 & 0 & 0 & 0 \\
\hline Natural conditions & 0 & 0 & 0 & 0 & 0 & 0 \\
\hline Economic and technical conditions & 0 & 0 & 0 & 0 & 0 & 0 \\
\hline $\begin{array}{l}\text { Rock-soil body type and combination } \\
\text { characteristics }\end{array}$ & 0 & 0 & 0 & 0 & 0 & 0 \\
\hline Rock and soil characteristics & 0 & 0 & 0 & 0 & 0 & 0 \\
\hline Impact of underground space development & 0 & 0 & 0 & 0 & 0 & 0 \\
\hline Site conditions & 0 & 0 & 0 & 0 & 0 & 0 \\
\hline Cost per unit area & 0 & 0 & 0 & 0 & 0 & 0 \\
\hline Existing facilities and various protection needs & 0 & 0 & 0 & 0 & 0 & 0 \\
\hline Socioeconomic factors & 0 & 0 & 0 & 0 & 0 & 0 \\
\hline Geological structure & 0 & 0 & 0 & 0 & 0 & 0 \\
\hline Geological disaster & 0 & 0 & 0 & 0 & 1 & 0 \\
\hline Environmental geology & 0 & 0 & 1 & 0 & 0 & 0 \\
\hline Human engineering activities & 0 & 0 & 0 & 0 & 0 & 0 \\
\hline Adverse geological effects & 0 & 1 & 0 & 1 & 0 & 1 \\
\hline Soil condition & 0 & 0 & 0 & 0 & 0 & 0 \\
\hline topography & 1 & 1 & 1 & 0 & 1 & 1 \\
\hline Engineering Geology & 1 & 1 & 1 & 1 & 0 & 0 \\
\hline Hydrogeology & 1 & 1 & 1 & 1 & 1 & 1 \\
\hline
\end{tabular}


Table A4. First level index binarization matrix.

\begin{tabular}{|c|c|c|c|c|c|c|}
\hline Index Level 1 & $\begin{array}{c}\text { Sen Liu, } \\
\text { Zhiliang Dong }\end{array}$ & $\begin{array}{l}\text { Hui Cao, } \\
\text { Hanyuan Yang, etc. }\end{array}$ & $\begin{array}{l}\text { Zhenyu Wang, } \\
\text { Taiyi Zhu, etc. }\end{array}$ & $\begin{array}{l}\text { Siyi Jiang, } \\
\text { Fu Wu, etc. }\end{array}$ & $\begin{array}{l}\text { Dingfang Xu, } \\
\text { Yang He, etc. }\end{array}$ & Caixiu Lin \\
\hline Site stability & 0 & 0 & 0 & 0 & 0 & 0 \\
\hline Current status of underground space & 0 & 0 & 0 & 0 & 0 & 0 \\
\hline Status of ground space & 0 & 0 & 0 & 0 & 0 & 0 \\
\hline $\begin{array}{l}\text { Protection and development of historical cultural } \\
\text { relics }\end{array}$ & 0 & 0 & 0 & 0 & 0 & 0 \\
\hline Spatial location conditions & 0 & 0 & 1 & 0 & 0 & 0 \\
\hline Sensitive factor & 0 & 0 & 0 & 0 & 0 & 0 \\
\hline Formation lithology & 0 & 0 & 0 & 0 & 0 & 0 \\
\hline Ground subsidence & 0 & 0 & 0 & 0 & 0 & 0 \\
\hline Rock conditions & 0 & 0 & 0 & 0 & 0 & 0 \\
\hline Bad rock and soil & 0 & 0 & 0 & 0 & 0 & 0 \\
\hline Building site category & 0 & 0 & 0 & 0 & 0 & 0 \\
\hline Sensitive factor & 1 & 0 & 0 & 0 & 0 & 0 \\
\hline City conditions & 0 & 0 & 1 & 0 & 0 & 0 \\
\hline Natural conditions & 0 & 0 & 1 & 0 & 0 & 0 \\
\hline Economic and technical conditions & 0 & 0 & 1 & 0 & 0 & 0 \\
\hline $\begin{array}{c}\text { Rock-soil body type and combination } \\
\text { characteristics }\end{array}$ & 0 & 0 & 0 & 0 & 1 & 0 \\
\hline Rock and soil characteristics & 0 & 0 & 0 & 0 & 0 & 0 \\
\hline Impact of underground space development & 0 & 0 & 0 & 0 & 0 & 0 \\
\hline Site conditions & 0 & 0 & 0 & 0 & 0 & 0 \\
\hline Cost per unit area & 0 & 0 & 0 & 0 & 0 & 0 \\
\hline Existing facilities and various protection needs & 0 & 0 & 0 & 0 & 0 & 0 \\
\hline Socioeconomic factors & 0 & 0 & 0 & 0 & 0 & 0 \\
\hline Geological structure & 1 & 0 & 0 & 0 & 1 & 0 \\
\hline Geological disaster & 0 & 1 & 0 & 0 & 0 & 0 \\
\hline Environmental geology & 0 & 0 & 0 & 0 & 0 & 1 \\
\hline Human engineering activities & 0 & 0 & 0 & 1 & 0 & 0 \\
\hline Adverse geological effects & 1 & 0 & 0 & 1 & 1 & 0 \\
\hline Soil condition & 0 & 0 & 0 & 0 & 0 & 0 \\
\hline topography & 1 & 1 & 0 & 1 & 1 & 1 \\
\hline Engineering Geology & 0 & 1 & 0 & 1 & 0 & 1 \\
\hline Hydrogeology & 1 & 1 & 0 & 1 & 1 & 1 \\
\hline
\end{tabular}

Table A5. First level index binarization matrix.

\begin{tabular}{|c|c|c|c|c|c|}
\hline Index Level 1 & $\begin{array}{l}\text { Wei Shi, } \\
\text { Youlin Wang }\end{array}$ & $\begin{array}{l}\text { Tuanzhi Zhao, } \\
\text { Yansheng Hou, etc. }\end{array}$ & Yong Tang & $\begin{array}{l}\text { Dankun Zhou, } \\
\text { Xiaozhao Li, etc. }\end{array}$ & $\begin{array}{l}\text { Zhongle Lu, } \\
\text { Li Wu, etc. }\end{array}$ \\
\hline Site stability & 0 & 0 & 0 & 0 & 0 \\
\hline Current status of underground space & 0 & 0 & 0 & 0 & 0 \\
\hline Status of ground space & 0 & 0 & 0 & 0 & 0 \\
\hline $\begin{array}{c}\text { Protection and development of historical cultural } \\
\text { relics }\end{array}$ & 0 & 0 & 0 & 0 & 0 \\
\hline Spatial location conditions & 0 & 0 & 0 & 0 & 0 \\
\hline Sensitive factor & 0 & 0 & 0 & 0 & 0 \\
\hline Formation lithology & 0 & 0 & 0 & 0 & 0 \\
\hline Ground subsidence & 0 & 0 & 0 & 0 & 0 \\
\hline Rock conditions & 0 & 1 & 0 & 0 & 1 \\
\hline Bad rock and soil & 0 & 0 & 0 & 0 & 0 \\
\hline Building site category & 0 & 0 & 0 & 0 & 0 \\
\hline Sensitive factor & 0 & 0 & 0 & 0 & 0 \\
\hline City conditions & 0 & 0 & 0 & 0 & 0 \\
\hline Natural conditions & 0 & 0 & 0 & 0 & 0 \\
\hline Economic and technical conditions & 0 & 1 & 0 & 0 & 0 \\
\hline Rock-soil body type and combination characteristics & 0 & 0 & 0 & 0 & 0 \\
\hline Rock and soil characteristics & 0 & 0 & 1 & 0 & 0 \\
\hline Impact of underground space development & 0 & 0 & 1 & 0 & 0 \\
\hline Site conditions & 0 & 0 & 1 & 0 & 0 \\
\hline Cost per unit area & 0 & 0 & 0 & 0 & 0 \\
\hline Existing facilities and various protection needs & 0 & 0 & 0 & 1 & 0 \\
\hline Socioeconomic factors & 0 & 0 & 0 & 1 & 0 \\
\hline Geological structure & 0 & 0 & 0 & 1 & 1 \\
\hline Geological disaster & 0 & 0 & 0 & 0 & 0 \\
\hline Environmental geology & 0 & 1 & 0 & 0 & 0 \\
\hline Human engineering activities & 0 & 0 & 0 & 0 & 0 \\
\hline Adverse geological effects & 1 & 0 & 0 & 0 & 1 \\
\hline Soil condition & 0 & 0 & 0 & 0 & 0 \\
\hline topography & 0 & 0 & 1 & 0 & 1 \\
\hline Engineering Geology & 1 & 0 & 0 & 0 & 0 \\
\hline Hydrogeology & 1 & 1 & 1 & 0 & 1 \\
\hline
\end{tabular}


Table A6. Second level index binarization matrix.

\begin{tabular}{|c|c|c|c|c|c|c|}
\hline Index Level 2 & $\begin{array}{c}\text { Kun Liu, } \\
\text { Jian Peng, etc. }\end{array}$ & $\begin{array}{c}\text { Sen Liu, } \\
\text { Zhiliang Dong }\end{array}$ & $\begin{array}{c}\text { Zhiqiang Xie, } \\
\text { Zhengang Zhai, etc. }\end{array}$ & $\begin{array}{c}\text { Jian Liu, } \\
\text { Yongyao Wei, etc. }\end{array}$ & $\begin{array}{c}\text { Zhen Zhou, } \\
\text { Wenbo Wu, etc. }\end{array}$ & $\begin{array}{c}\text { Hui Tang, } \\
\text { Heng Kuang, etc. }\end{array}$ \\
\hline Elevation & 1 & 0 & 0 & 0 & 0 & 0 \\
\hline Ground slope & 1 & 0 & 1 & 0 & 0 & 0 \\
\hline Landform type & 0 & 1 & 0 & 0 & 0 & 1 \\
\hline Feature type & 0 & 0 & 0 & 0 & 0 & 0 \\
\hline Geomorphological unit & 0 & 0 & 0 & 1 & 1 & 0 \\
\hline Natural elevation & 0 & 1 & 0 & 0 & 0 & 0 \\
\hline Terrain conditions & 0 & 0 & 0 & 0 & 0 & 0 \\
\hline
\end{tabular}

Table A7. Second level index binarization matrix.

\begin{tabular}{ccccc}
\hline Index Level 2 & $\begin{array}{c}\text { Xin Tang, } \\
\text { Jian Liu, etc. }\end{array}$ & Ting Jiang & $\begin{array}{c}\text { Sen Liu, } \\
\text { Zhiliang Dong }\end{array}$ & $\begin{array}{c}\text { Hui Cao, } \\
\text { Hanyuan Yang, etc. }\end{array}$ \\
\hline Elevation & 0 & 0 & 0 & $\begin{array}{c}\text { Siyi Jiang, } \\
\text { Fu Wu, etc. }\end{array}$ \\
Ground slope & 0 & 0 & 0 & 0 \\
Yang He, etc.
\end{tabular}

Table A8. Second level index binarization matrix.

\begin{tabular}{cccc}
\hline Index Level 2 & Caixiu Lin & Yong Tang & Zhongle Lu, Li Wu, etc. \\
\hline Elevation & 0 & 0 & 0 \\
Ground slope & 0 & 0 & 1 \\
Landform type & 1 & 0 & 0 \\
Feature type & 0 & 1 & 0 \\
Geomorphological unit & 0 & 0 & 0 \\
Natural elevation & 0 & 0 & 0 \\
Terrain conditions & 0 & 0 & 0 \\
\hline
\end{tabular}

Table A9. Second level index binarization matrix.

\begin{tabular}{|c|c|c|c|c|c|c|}
\hline Index Level 2 & $\begin{array}{l}\text { Maosheng Zhang, } \\
\text { Tonglu Li, etc. }\end{array}$ & $\begin{array}{l}\text { Ping Zhang, } \\
\text { Yu Xiao }\end{array}$ & $\begin{array}{l}\text { Kun Liu, } \\
\text { Jian Peng, etc. }\end{array}$ & $\begin{array}{c}\text { Sen Liu, } \\
\text { Zhiliang Dong }\end{array}$ & $\begin{array}{c}\text { Xingxin Liu, } \\
\text { Haiyou Peng, etc. }\end{array}$ & $\begin{array}{l}\text { Pinrui Qin, } \\
\text { Shuai Gao, etc. }\end{array}$ \\
\hline Depth of water level & 1 & 1 & 1 & 0 & 0 & 1 \\
\hline Aquifer thickness & 0 & 0 & 1 & 0 & 0 & 1 \\
\hline Groundwater corrosivity & 0 & 1 & 1 & 1 & 1 & 1 \\
\hline Groundwater rich in water & 0 & 0 & 0 & 1 & 0 & 1 \\
\hline Minimum depth of groundwater level & 0 & 0 & 0 & 1 & 0 & 0 \\
\hline $\begin{array}{l}\text { The influence of underground river on } \\
\text { underground space development }\end{array}$ & 0 & 0 & 0 & 0 & 0 & 0 \\
\hline Groundwater type & 0 & 0 & 0 & 0 & 0 & 0 \\
\hline Groundwater resources modulus & 0 & 0 & 0 & 0 & 0 & 0 \\
\hline Groundwater pollution & 0 & 0 & 0 & 0 & 0 & 0 \\
\hline Surface water & 0 & 0 & 0 & 1 & 0 & 0 \\
\hline Water inflow of diving unit & 1 & 0 & 0 & 0 & 0 & 1 \\
\hline Weihe River flood disaster & 0 & 0 & 0 & 0 & 0 & 0 \\
\hline Confined water depth & 0 & 0 & 0 & 0 & 0 & 0 \\
\hline Aquifer permeability coefficient & 0 & 0 & 0 & 0 & 0 & 0 \\
\hline Permeability & 0 & 0 & 0 & 0 & 0 & 0 \\
\hline $\begin{array}{c}\text { Thickness of high permeability } \\
\text { phreatic aquifer }\end{array}$ & 0 & 0 & 0 & 0 & 0 & 0 \\
\hline Surge stability safety factor & 0 & 0 & 0 & 0 & 0 & 0 \\
\hline $\begin{array}{l}\text { The relationship between the bottom of the } \\
\text { pit and the bottom of the foundation }\end{array}$ & 0 & 0 & 0 & 0 & 0 & 0 \\
\hline Minimum depth of groundwater level & 0 & 0 & 0 & 0 & 0 & 0 \\
\hline $\begin{array}{c}\text { Impact of water quality on underground } \\
\text { engineering }\end{array}$ & 1 & 0 & 0 & 0 & 0 & 0 \\
\hline Soil thickness and distribution & 0 & 0 & 0 & 0 & 0 & 0 \\
\hline $\begin{array}{l}\text { Single well water inflow in confined } \\
\text { submerged section }\end{array}$ & 0 & 0 & 0 & 0 & 0 & 0 \\
\hline Absolute elevation of confined water head & 0 & 1 & 0 & 0 & 0 & 0 \\
\hline Buried depth of confined water layer roof & 0 & 1 & 0 & 0 & 0 & 0 \\
\hline Groundwater conditions & 0 & 0 & 0 & 0 & 1 & 0 \\
\hline
\end{tabular}


Table A9. Cont.

\begin{tabular}{ccccc}
\hline Index Level 2 & $\begin{array}{c}\text { Maosheng Zhang, } \\
\text { Tonglu Li, etc. }\end{array}$ & $\begin{array}{c}\text { Ping Zhang, } \\
\text { Yu Xiao }\end{array}$ & $\begin{array}{c}\text { Kun Liu, } \\
\text { Jian Peng, etc. }\end{array}$ & $\begin{array}{c}\text { Sen Liu, } \\
\text { Zhiliang Dong }\end{array}$ \\
$\begin{array}{c}\text { Xingxin Liu, } \\
\text { Haiyou Peng, etc. }\end{array}$ & $\begin{array}{c}\text { Pinrui Qin, } \\
\text { Shuai Gao, etc. }\end{array}$ \\
\hline Water-bearing rock group type & 0 & 0 & 0 & 0 \\
Buried depth of confined water root & 0 & 0 & 0 & 0 \\
Confined head pressure & 0 & 0 & 0 & 0 \\
Water layer sensitivity & 0 & 0 & 0 & 0 \\
Flood & 0 & 0 & 0 & 0 \\
Karst & 0 & 0 & 0 & 0 \\
Distance to surface water & 0 & 0 & 0 & 0 \\
\hline
\end{tabular}

Table A10. Second level index binarization matrix.

\begin{tabular}{|c|c|c|c|c|c|c|}
\hline Index Level 2 & $\begin{array}{c}\text { Ming Yang, } \\
\text { Chenghe Zhu, etc. }\end{array}$ & $\begin{array}{c}\text { Jian Liu, } \\
\text { Yongyao Wei, etc. }\end{array}$ & $\begin{array}{c}\text { Zhen Zhou, } \\
\text { Wenbo Wu, etc. }\end{array}$ & $\begin{array}{c}\text { Jinxiu Lao, } \\
\text { Naiyi Wei, etc. }\end{array}$ & $\begin{array}{c}\text { Nian Ren, } \\
\text { Jiang Xiao, etc. }\end{array}$ & $\begin{array}{c}\text { Hui Tang, } \\
\text { Heng Kuang, etc. }\end{array}$ \\
\hline Depth of water level & 0 & 0 & 0 & 0 & 1 & 1 \\
\hline Aquifer thickness & 0 & 0 & 0 & 1 & 0 & 1 \\
\hline Groundwater corrosivity & 1 & 0 & 0 & 0 & 0 & 1 \\
\hline Groundwater rich in water & 1 & 0 & 0 & 0 & 1 & 1 \\
\hline Minimum depth of groundwater level & 0 & 0 & 0 & 0 & 0 & 0 \\
\hline $\begin{array}{l}\text { The influence of underground river on } \\
\text { underground space development }\end{array}$ & 0 & 0 & 0 & 0 & 0 & 0 \\
\hline Groundwater type & 0 & 0 & 0 & 0 & 0 & 0 \\
\hline Groundwater resources modulus & 0 & 0 & 0 & 0 & 0 & 0 \\
\hline Groundwater pollution & 0 & 0 & 0 & 0 & 0 & 0 \\
\hline Surface water & 1 & 1 & 1 & 0 & 0 & 0 \\
\hline Water inflow of diving unit & 0 & 1 & 0 & 0 & 0 & 0 \\
\hline Weihe River flood disaster & 0 & 0 & 0 & 0 & 0 & 0 \\
\hline Confined water depth & 0 & 0 & 0 & 0 & 0 & 0 \\
\hline Aquifer permeability coefficient & 0 & 0 & 0 & 0 & 0 & 0 \\
\hline Permeability & 0 & 0 & 0 & 0 & 0 & 0 \\
\hline $\begin{array}{c}\text { Thickness of high permeability } \\
\text { phreatic aquifer }\end{array}$ & 0 & 0 & 0 & 0 & 0 & 0 \\
\hline Surge stability safety factor & 0 & 0 & 0 & 0 & 0 & 0 \\
\hline $\begin{array}{l}\text { The relationship between the bottom of } \\
\text { the pit and the bottom of the foundation }\end{array}$ & 0 & 0 & 0 & 0 & 0 & 0 \\
\hline Minimum depth of groundwater level & 1 & 0 & 0 & 0 & 0 & 0 \\
\hline $\begin{array}{l}\text { Impact of water quality on } \\
\text { underground engineering }\end{array}$ & 0 & 0 & 0 & 0 & 0 & 0 \\
\hline Soil thickness and distribution & 0 & 0 & 1 & 0 & 0 & 0 \\
\hline $\begin{array}{l}\text { Single well water inflow in confined } \\
\text { submerged section }\end{array}$ & 0 & 0 & 1 & 0 & 0 & 0 \\
\hline $\begin{array}{l}\text { Absolute elevation of confined } \\
\text { water head }\end{array}$ & 0 & 0 & 0 & 0 & 0 & 0 \\
\hline Buried depth of confined water layer roof & 0 & 0 & 0 & 0 & 0 & 0 \\
\hline Groundwater conditions & 0 & 0 & 0 & 0 & 0 & 0 \\
\hline Water-bearing rock group type & 0 & 0 & 0 & 0 & 1 & 0 \\
\hline Buried depth of confined water roof & 0 & 0 & 0 & 0 & 0 & 0 \\
\hline Confined head pressure & 0 & 0 & 0 & 0 & 0 & 0 \\
\hline Water layer sensitivity & 0 & 0 & 0 & 0 & 0 & 0 \\
\hline Flood & 0 & 0 & 0 & 0 & 0 & 0 \\
\hline Karst & 0 & 0 & 1 & 0 & 0 & 0 \\
\hline Distance to surface water & 0 & 0 & 0 & 0 & 1 & 0 \\
\hline
\end{tabular}

Table A11. Second level index binarization matrix.

\begin{tabular}{|c|c|c|c|c|c|c|}
\hline Index Level 2 & $\begin{array}{c}\text { Hui Li, } \\
\text { Wei Shi, etc. }\end{array}$ & $\begin{array}{c}\text { Xin Tang, } \\
\text { Jian Liu, etc. }\end{array}$ & Ting Jiang & $\begin{array}{c}\text { Sen Liu, } \\
\text { Zhiliang Dong }\end{array}$ & $\begin{array}{c}\text { Hui Cao, } \\
\text { Hanyuan Yang, etc. }\end{array}$ & $\begin{array}{l}\text { Siyi Jiang, } \\
\text { Fu Wu, etc. }\end{array}$ \\
\hline Depth of water level & 0 & 0 & 1 & 1 & 1 & 0 \\
\hline Aquifer thickness & 1 & 0 & 0 & 1 & 0 & 0 \\
\hline Groundwater corrosivity & 0 & 0 & 0 & 1 & 0 & 0 \\
\hline Groundwater rich in water & 0 & 1 & 0 & 0 & 0 & 1 \\
\hline Minimum depth of groundwater level & 0 & 0 & 0 & 0 & 0 & 1 \\
\hline $\begin{array}{l}\text { The influence of underground river on } \\
\text { underground space development }\end{array}$ & 0 & 0 & 0 & 0 & 0 & 1 \\
\hline Groundwater type & 0 & 0 & 0 & 0 & 1 & 0 \\
\hline Groundwater resources modulus & 0 & 0 & 0 & 0 & 1 & 0 \\
\hline Groundwater pollution & 0 & 0 & 0 & 0 & 1 & 0 \\
\hline Surface water & 1 & 0 & 0 & 0 & 0 & 0 \\
\hline Water inflow of diving unit & 1 & 0 & 0 & 0 & 0 & 0 \\
\hline
\end{tabular}


Table A11. Cont.

\begin{tabular}{|c|c|c|c|c|c|c|}
\hline Index Level 2 & $\begin{array}{c}\text { Hui Li, } \\
\text { Wei Shi, etc. }\end{array}$ & $\begin{array}{l}\text { Xin Tang, } \\
\text { Jian Liu, etc. }\end{array}$ & Ting Jiang & $\begin{array}{c}\text { Sen Liu, } \\
\text { Zhiliang Dong }\end{array}$ & $\begin{array}{c}\text { Hui Cao, } \\
\text { Hanyuan Yang, etc. }\end{array}$ & $\begin{array}{l}\text { Siyi Jiang, } \\
\text { Fu Wu, etc. }\end{array}$ \\
\hline Weihe River flood disaster & 1 & 0 & 0 & 0 & 0 & 0 \\
\hline Confined water depth & 0 & 0 & 0 & 0 & 0 & 0 \\
\hline Aquifer permeability coefficient & 0 & 0 & 0 & 0 & 0 & 0 \\
\hline Permeability & 0 & 0 & 0 & 0 & 0 & 0 \\
\hline $\begin{array}{l}\text { Thickness of high permeability } \\
\text { phreatic aquifer }\end{array}$ & 0 & 0 & 0 & 0 & 0 & 0 \\
\hline Surge stability safety factor & 0 & 0 & 0 & 0 & 0 & 0 \\
\hline $\begin{array}{l}\text { The relationship between the bottom of the } \\
\text { pit and the bottom of the foundation }\end{array}$ & 0 & 0 & 0 & 0 & 0 & 0 \\
\hline Minimum depth of groundwater level & 0 & 0 & 0 & 0 & 0 & 0 \\
\hline $\begin{array}{l}\text { Impact of water quality on } \\
\text { underground engineering }\end{array}$ & 0 & 0 & 0 & 0 & 0 & 0 \\
\hline Soil thickness and distribution & 0 & 0 & 0 & 0 & 0 & 0 \\
\hline $\begin{array}{l}\text { Single well water inflow in confined } \\
\text { submerged section }\end{array}$ & 0 & 0 & 0 & 0 & 0 & 0 \\
\hline Absolute elevation of confined water head & 0 & 0 & 0 & 0 & 0 & 0 \\
\hline Buried depth of confined water layer roof & 0 & 0 & 0 & 0 & 0 & 0 \\
\hline Groundwater conditions & 0 & 0 & 0 & 0 & 0 & 0 \\
\hline Water-bearing rock group type & 0 & 0 & 0 & 0 & 0 & 0 \\
\hline Buried depth of confined water roof & 0 & 0 & 0 & 0 & 0 & 0 \\
\hline Confined head pressure & 0 & 0 & 0 & 0 & 0 & 0 \\
\hline Water layer sensitivity & 0 & 0 & 0 & 0 & 0 & 0 \\
\hline Flood & 0 & 0 & 0 & 0 & 0 & 0 \\
\hline Karst & 0 & 0 & 0 & 0 & 0 & 0 \\
\hline Distance to surface water & 0 & 0 & 0 & 0 & 0 & 0 \\
\hline
\end{tabular}

Table A12. Second level index binarization matrix.

\begin{tabular}{|c|c|c|c|c|c|c|}
\hline Index Level 2 & $\begin{array}{l}\text { Dingfang Xu, } \\
\text { Yang He, etc. }\end{array}$ & Caixiu Lin & $\begin{array}{l}\text { Wei Shi, } \\
\text { Youlin Wang }\end{array}$ & $\begin{array}{l}\text { Tuanzhi Zhao, } \\
\text { Yansheng Hou, etc. }\end{array}$ & Yong Tang & $\begin{array}{l}\text { Zhongle Lu, } \\
\text { Li Wu, etc. }\end{array}$ \\
\hline Depth of water level & 1 & 1 & 0 & 1 & 0 & 1 \\
\hline Aquifer thickness & 0 & 1 & 1 & 1 & 0 & 0 \\
\hline Groundwater corrosivity & 1 & 1 & 0 & 1 & 1 & 0 \\
\hline Groundwater rich in water & 1 & 0 & 0 & 0 & 0 & 0 \\
\hline Minimum depth of groundwater level & 0 & 0 & 0 & 0 & 0 & 0 \\
\hline $\begin{array}{l}\text { The influence of underground river on underground } \\
\text { space development }\end{array}$ & 0 & 0 & 0 & 0 & 0 & 0 \\
\hline Groundwater type & 0 & 0 & 0 & 0 & 0 & 0 \\
\hline Groundwater resources modulus & 0 & 0 & 0 & 0 & 0 & 0 \\
\hline Groundwater pollution & 0 & 0 & 0 & 0 & 0 & 0 \\
\hline Surface water & 0 & 0 & 1 & 0 & 0 & 0 \\
\hline Water inflow of diving unit & 0 & 0 & 1 & 0 & 0 & 0 \\
\hline Weihe River flood disaster & 0 & 0 & 1 & 0 & 0 & 0 \\
\hline Confined water depth & 0 & 0 & 0 & 1 & 0 & 0 \\
\hline Aquifer permeability coefficient & 0 & 1 & 0 & 0 & 0 & 0 \\
\hline Permeability & 0 & 0 & 0 & 0 & 1 & 0 \\
\hline Thickness of high permeability phreatic aquifer & 0 & 0 & 0 & 0 & 1 & 0 \\
\hline Surge stability safety factor & 0 & 0 & 0 & 0 & 1 & 0 \\
\hline $\begin{array}{l}\text { The relationship between the bottom of the pit and } \\
\text { the bottom of the foundation }\end{array}$ & 0 & 0 & 0 & 0 & 1 & 0 \\
\hline Minimum depth of groundwater level & 0 & 0 & 0 & 0 & 0 & 0 \\
\hline Impact of water quality on underground engineering & 0 & 0 & 0 & 0 & 0 & 0 \\
\hline Soil thickness and distribution & 0 & 0 & 0 & 0 & 0 & 0 \\
\hline $\begin{array}{l}\text { Single well water inflow in confined } \\
\text { submerged section }\end{array}$ & 0 & 0 & 0 & 0 & 0 & 0 \\
\hline Absolute elevation of confined water head & 0 & 0 & 0 & 0 & 0 & 0 \\
\hline Buried depth of confined water layer roof & 0 & 0 & 0 & 0 & 0 & 0 \\
\hline Groundwater conditions & 0 & 0 & 0 & 0 & 0 & 0 \\
\hline Water-bearing rock group type & 1 & 0 & 0 & 0 & 0 & 0 \\
\hline Buried depth of confined water roof & 1 & 0 & 0 & 0 & 0 & 0 \\
\hline Confined head pressure & 1 & 0 & 0 & 0 & 0 & 0 \\
\hline Water layer sensitivity & 0 & 0 & 0 & 0 & 0 & 1 \\
\hline Flood & 0 & 0 & 0 & 0 & 0 & 1 \\
\hline Karst & 0 & 0 & 0 & 0 & 0 & 1 \\
\hline Distance to surface water & 0 & 0 & 0 & 0 & 0 & 0 \\
\hline
\end{tabular}


Table A13. Second level index binarization matrix.

\begin{tabular}{|c|c|c|c|c|c|c|}
\hline Index Level 2 & $\begin{array}{l}\text { Ping Zhang, } \\
\text { Yu Xiao }\end{array}$ & $\begin{array}{c}\text { Kun Liu, } \\
\text { Jian Peng, etc. }\end{array}$ & $\begin{array}{l}\text { Pinrui Qin, } \\
\text { Shuai Gao, etc. }\end{array}$ & $\begin{array}{l}\text { Ming Yang, } \\
\text { Chenghe Zhu, etc. }\end{array}$ & $\begin{array}{c}\text { Zhen Zhou, } \\
\text { Wenbo Wu, etc. }\end{array}$ & $\begin{array}{l}\text { Jinxiu Lao, } \\
\text { Naiyi Wei, etc. }\end{array}$ \\
\hline Soil uniformity & 1 & 1 & 0 & 1 & 0 & 1 \\
\hline Soft soil thickness & 0 & 1 & 1 & 1 & 0 & 0 \\
\hline topography & 1 & 1 & 0 & 1 & 1 & 0 \\
\hline Weak rock and soil & 1 & 0 & 0 & 0 & 0 & 0 \\
\hline Hydrological conditions & 0 & 0 & 0 & 0 & 0 & 0 \\
\hline Geological disaster & 0 & 0 & 0 & 0 & 0 & 0 \\
\hline city environment & 0 & 0 & 0 & 0 & 0 & 0 \\
\hline Fault structure & 0 & 0 & 0 & 0 & 0 & 0 \\
\hline Comprehensive Zoning of Rock and Soil & 0 & 0 & 0 & 0 & 0 & 0 \\
\hline Collapsible loess & 0 & 0 & 1 & 0 & 0 & 0 \\
\hline $\begin{array}{l}\text { Yangtze River low floodplain sedimentary } \\
\text { engineering geological area }\end{array}$ & 0 & 0 & 1 & 0 & 0 & 0 \\
\hline $\begin{array}{c}\text { Yangtze River High Floodplain } \\
\text { Sedimentary Engineering Geological Area }\end{array}$ & 0 & 0 & 1 & 0 & 0 & 0 \\
\hline Hidden terrace engineering geological area & 0 & 0 & 0 & 1 & 0 & 0 \\
\hline $\begin{array}{l}\text { Lixiahe lacustrine sedimentary engineering } \\
\text { geological area }\end{array}$ & 0 & 1 & 0 & 0 & 0 & 0 \\
\hline Number of fault layers and folds & 0 & 0 & 0 & 0 & 1 & 0 \\
\hline Allowable bearing capacity of soil layer & 0 & 0 & 0 & 0 & 1 & 0 \\
\hline seismic intensity & 0 & 0 & 0 & 0 & 1 & 0 \\
\hline Liquefied soil layer & 0 & 0 & 0 & 0 & 1 & 0 \\
\hline Expansive Soil & 0 & 0 & 0 & 0 & 0 & 0 \\
\hline Internal friction angle & 0 & 0 & 0 & 0 & 0 & 0 \\
\hline Soil cohesion & 0 & 0 & 0 & 0 & 0 & 0 \\
\hline Compression modulus & 0 & 0 & 0 & 0 & 0 & 0 \\
\hline Rock and soil category & 0 & 0 & 0 & 0 & 0 & 0 \\
\hline Formation lithology & 0 & 0 & 0 & 0 & 0 & 0 \\
\hline Host thickness & 0 & 0 & 0 & 0 & 0 & 0 \\
\hline Rock and soil structure & 1 & 0 & 0 & 0 & 0 & 0 \\
\hline Geological structure & 1 & 0 & 0 & 0 & 0 & 0 \\
\hline Suitability of soil foundation & 1 & 0 & 0 & 0 & 0 & 0 \\
\hline Geological capacity & 0 & 0 & 0 & 0 & 0 & 1 \\
\hline
\end{tabular}

Table A14. Second level index binarization matrix.

\begin{tabular}{|c|c|c|c|c|c|c|}
\hline Index Level 2 & $\begin{array}{c}\text { Hui Tang, } \\
\text { Heng Kuang, etc. }\end{array}$ & $\begin{array}{c}\text { Hui Li, } \\
\text { Wei Shi, etc. }\end{array}$ & $\begin{array}{c}\text { Hui Cao, } \\
\text { Hanyuan Yang, etc. }\end{array}$ & $\begin{array}{l}\text { Siyi Jiang, } \\
\text { Fu Wu, etc. }\end{array}$ & Caixiu Lin & $\begin{array}{l}\text { Wei Shi, } \\
\text { Youlin Wang }\end{array}$ \\
\hline Soil uniformity & 1 & 0 & 0 & 0 & 0 & 0 \\
\hline Soft soil thickness & 0 & 0 & 0 & 1 & 0 & 0 \\
\hline topography & 0 & 0 & 0 & 0 & 0 & 1 \\
\hline Weak rock and soil & 0 & 0 & 0 & 0 & 0 & 0 \\
\hline Hydrological conditions & 0 & 0 & 0 & 0 & 0 & 0 \\
\hline Geological disaster & 0 & 0 & 0 & 0 & 0 & 0 \\
\hline city environment & 0 & 0 & 0 & 0 & 0 & 0 \\
\hline Fault structure & 0 & 0 & 0 & 0 & 0 & 0 \\
\hline Comprehensive Zoning of Rock and Soil & 0 & 0 & 0 & 0 & 0 & 0 \\
\hline Collapsible loess & 0 & 1 & 0 & 0 & 0 & 0 \\
\hline $\begin{array}{c}\text { Yangtze River low floodplain sedimentary } \\
\text { engineering geological area }\end{array}$ & 0 & 0 & 0 & 0 & 0 & 0 \\
\hline $\begin{array}{c}\text { Yangtze River High Floodplain Sedimentary } \\
\text { Engineering Geological Area }\end{array}$ & 0 & 0 & 0 & 0 & 0 & 0 \\
\hline Hidden terrace engineering geological area & 0 & 0 & 0 & 0 & 0 & 0 \\
\hline $\begin{array}{l}\text { Lixiahe lacustrine sedimentary engineering } \\
\text { geological area }\end{array}$ & 0 & 0 & 0 & 0 & 0 & 0 \\
\hline Number of fault layers and folds & 0 & 0 & 0 & 0 & 0 & 0 \\
\hline Allowable bearing capacity of soil layer & 0 & 0 & 0 & 0 & 0 & 0 \\
\hline seismic intensity & 0 & 0 & 0 & 0 & 0 & 0 \\
\hline Liquefied soil layer & 0 & 0 & 0 & 0 & 0 & 0 \\
\hline Expansive Soil & 0 & 0 & 0 & 0 & 0 & 0 \\
\hline Internal friction angle & 0 & 0 & 0 & 0 & 1 & 0 \\
\hline Soil cohesion & 0 & 0 & 0 & 0 & 1 & 0 \\
\hline Compression modulus & 0 & 0 & 0 & 0 & 1 & 0 \\
\hline Rock and soil category & 0 & 0 & 1 & 0 & 1 & 0 \\
\hline Formation lithology & 0 & 0 & 0 & 0 & 1 & 0 \\
\hline Host thickness & 1 & 0 & 0 & 0 & 0 & 0 \\
\hline Rock and soil structure & 0 & 1 & 1 & 1 & 0 & 1 \\
\hline Geological structure & 0 & 1 & 0 & 0 & 0 & 1 \\
\hline Suitability of soil foundation & 0 & 0 & 0 & 1 & 0 & 0 \\
\hline Geological capacity & 0 & 0 & 1 & 0 & 0 & 0 \\
\hline
\end{tabular}

\section{References}

1. Kirkby, R.J.R. Urbanization in China: Town and Country in a Developing Economy 1949-2000 AD; Routledge: Oxford, UK, 2018.

2. Kalnay, E.; Cai, M. Impact of urbanization and land-use change on climate. Nature 2003, 423, 528. [CrossRef]

3. Zhang, P.Y. Urban Regeneration: Theory and Practice in China's New Urbanization. City Plan. Rev. 2004, 4, 7. 
4. Madgin, R. Reconceptualising the historic urban environment: Conservation and regeneration in Castlefield, Manchester, 1960-2009. Plan. Perspect. 2010, 25, 29-48. [CrossRef]

5. Nasser, N. Planning for Urban Heritage Places: Reconciling Conservation, Tourism, and Sustainable Development. J. Plan. Lit. 2003, 17, 467-479. [CrossRef]

6. Lewis, P.G. Looking outward or turning inward? Motivations for development decisions in California central cities and suburbs. Urban Aff. Rev. 2001, 36, 696-720. [CrossRef]

7. Edelenbos, J.; Monnikhof, R.; Haasnoot, J.; Van Der Hoeven, F.; Horvat, E.; Van Der Krogt, R. Strategic study on the utilization of underground space in the Netherlands. Tunn. Undergr. Space Technol. 1988, 13, 159-165. [CrossRef]

8. Rönkä, K.; Ritola, J.; Rauhala, K. Underground space in land-use planning. Tunn. Undergr. Space Technol. 1998, 13, 39-49. [CrossRef]

9. Peng, J.; Peng, F.-L. A GIS-based evaluation method of underground space resources for urban spatial planning: Part 1 methodology. Tunn. Undergr. Space Technol. 2018, 74, 82-95. [CrossRef]

10. Zhang, P.; Chen, Z.L.; Huang, O.L.; Wang, H. Historical District Preservation and Underground Space Development. Planners 2011, 27, 97-101.

11. Jordan, D.P. Haussmann and Haussmannisation: The Legacy for Paris. Fr. Hist. Stud. 2004, 27, 87-113. [CrossRef]

12. Roberts, P.; Sykes, H.; Granger, R. Urban Regeneration; Sage: Los Angeles, CA, USA, 2016.

13. Roberts, P.; Sykes, H. Urban Regeneration: A Handbook; Sage: Los Angeles, CA, USA, 1999.

14. Tallon, A. Urban Regeneration in the UK; Routledge: Oxford, UK, 2013.

15. Frey, W.H. The New Urban Revival in the United States. Urban Stud. 1993, 30, 741-774. [CrossRef]

16. Sterling, R.; Nelson, S.R.; Jaffe, M.S. Planning for Underground Space: American Planning Association; American Planning Association: Chicago, IL, USA, 1983.

17. Sterling, R.L.; Nelson, S.R.; Yang, Y.J. Technical Guidelines for Underground Space Planning. Undergr. Space. 1983, 3, 46-58.

18. Sterling, R. Underground technologies for livable cities. Tunn. Undergr. Space Technol. 1997, 12, 479-490. [CrossRef]

19. Shi, X.D. History and Future of Underground Space Development and Utilization in Beijing. Chin. J. Undergr. Space Eng. 2006, 2, 1088-1092.

20. Hunt, D.; Makana, L.; Jefferson, I.; Rogers, C. Liveable cities and urban underground space. Tunn. Undergr. Space Technol. 2016, 55, 8-20. [CrossRef]

21. Vähäaho, I. Underground space planning in Helsinki. J. Rock Mech. Geotech. Eng. 2014, 6, 387-398. [CrossRef]

22. De Rienzo, F.; Oreste, P.; Pelizza, S. 3D GIS Supporting Underground Urbanisation in the City of Turin (Italy). Geotech. Geol. Eng. 2009, 27, 539-547. [CrossRef]

23. Maurenbrecher, P.; Herbschleb, J. The Potential Use of Geotechnical Information Systems in the Planning of Tunnels for Amsterdam. Tunn. Undergr. Space Technol. 1994, 9, 189-199. [CrossRef]

24. Godard, J.P. Urban Underground Space and Benefits of Going Underground. In Proceedings of the 30th ITA-AITES World Tunnel Congress, Singapore, 22-27 May 2004.

25. Dashko, R.; Ya, K. Underground space of saint-petersburg as a multicomponent system: Engineering geological and geotechnical aspects of its development. Int. Multidiscip. Sci. GeoConference Surv. Geol. Min. Ecol. Manag. SGEM 2015, 2, 827-883.

26. Sun, Y.J.; Dong, G.J. The Mode by Combining into Development of Underground Space and Protection of Cultural Relics-In the Famous Historical City of Luoyang as an Example. Adv. Mater. Res. 2011, 243-249, 6900-6903. [CrossRef]

27. Zhang, P.; Chen, Z.L.; Yang, H.Y.; Wang, H. On utilization of underground space to protect historical relics model. Tunn. Undergr. Space Technol. 2009, 24, 245-249.

28. Zhang, P.; Chen, Z.L. Protection of Historical Cultural Relics and the Development and Utilization of Underground Space. Chin. J. Undergr. Space Eng. 2006, 43, 229-232.

29. Admiraal, H.; Cornaro, A. Why underground space should be included in urban planning policy-And how this will enhance an urban underground future. Tunn. Undergr. Space Technol. 2016, 55, 214-220. [CrossRef]

30. Bobylev, N. Underground space in the Alexanderplatz area, Berlin: Research into the quantification of urban underground space use. Tunn. Undergr. Space Technol. 2010, 25, 495-507. [CrossRef]

31. Montazerolhodjah, M.; Pourjafar, M.; Taghvaee, A. Urban underground development an overview of historical underground cities in Iran. Iran Univ. Sci. Technol. 2015, 25, 53-60.

32. Li, X.; Li, C.; Parriaux, A.; Wu, W.; Li, H.; Sun, L.; Liu, C. Multiple resources and their sustainable development in Urban Underground Space. Tunn. Undergr. Space Technol. 2016, 55, 59-66. [CrossRef]

33. Guo, J.M.; Zhu, W.J. Potential value evaluation of underground space resource based on AHP method. Chin. J. Undergr. Space Eng. 2005, 1, 654-664.

34. Zhang, P. Evaluation method for the development suitability of underground space resources of historical relics J. PLA Univ. Sci. Technol. 2014, 15, 203-208. [CrossRef]

35. Zhu, Y.G.; Zhao, J.W.; Huang, Z.Y. Evaluation of underground space development value of historical block based on AHP. Chin. J. Undergr. Space Eng. 2018, 14, 1437-1444.

36. Qin, J.; Fang, C.; Wang, Y.; Chuanglin, F.; Wang, S. Evaluation of three-dimensional urban expansion: A case study of Yangzhou City, Jiangsu Province, China. Chin. Geogr. Sci. 2015, 25, 224-236. [CrossRef] 
37. Li, M.; Bao, H. An Attempt to Discuss the Types and Features of the Famous Historical Cultural Cities in China. Geogr. Res. 1996, 32, 1344-1351.

38. Altenburger, R.; Wan, M.B.; Børdahl, V. Yangzhou, A Place in Literature: The Local in Chinese Cultural History; University of Hawaii Press: Honolulu, HI, USA, 2015.

39. Xing, N.; Minghao, O. A study on driving-force system of regional land-use change: Taking yangzhou city as an example. China Popul. Resour. Environ. 2007, 17, 102-108.

40. Yu, L.; Nie, Y.; Zhu, C. Relations Analysis between Canal and Urban Development of Yangzhou Supported by Space Technology. In Proceedings of the 2011 International Conference on Image Analysis and Signal Processing (IASP 2011), Wuhan, China, 21-23 October 2011

41. Wu, Z.; Wang, H. Establishment and optimization of green ecological networks in Yangzhou City. Chin. J. Ecol. 2015, 34, 1976-1985.

42. Huang, J.; Zhu, X.; Mao, F.; Zhou, W.; Tang, Z. Yangzhou City land use dynamic monitoring using multi-temporal remote sensing techniques. In Proceedings of the Geoinformatics 2008 and Joint Conference on GIS and Built Environment: The Built Environment and Its Dynamics, SPIE, Guangzhou, China, 28-29 June 2008; Volume 7144, p. 71440.

43. Yuan, D. Yangzhou, a City Full of Charm in China. Voice Friendsh. 2013, 4, 18-20.

44. Yang, J.; Zhang, J.C.; Zhuang, J.R.; Mao, F. Study on Urban Change of the Yangzhou City within 2500 Years Based on 3S. Acta Sci. Nat. Univ. Pekin. 2012, 48, 459-468.

45. Shen, A.N. Historic Scenes in Yangzhou. China World Cult. Exch. 2012, 4, 40-43.

46. Gao, X.R.; Yang, N. Establishment of the Index System for Paper Evaluation by Social Network Analysis. Inf. Sci. 2017, 35, 97-102.

47. Liu, G. Landscape Evaluation of Southern Campus of Northwest University of Agriculture and Forestry Science and Technology; Northwest University of agriculture and forestry science and technology: Xianyang, China, 2019.

48. Di Nola, A.; Pedrycz, W.; Sessa, S.; Sanchez, E. Fuzzy relation equations theory as a basis of fuzzy modelling: An overview. Fuzzy Sets Syst. 1991, 40, 415-429. [CrossRef]

49. Lin, M.N. Evaluation on Development Potential of Urban Underground Space in Kunming; Kunming University of Technology: Kunming, China, 2019.

50. He, L.; Song, Y.; Dai, S.Z.; Durbak, K. Quantitative research on the capacity of urban underground space-the case of Shanghai, China. Tunn. Undergr. Space Technol. 2012, 32, 168-179. [CrossRef]

51. Gale, M.R.; Grigal, D.F. Vertical root distributions of northern tree species in relation to successional status. Can. J. For. Res. 1987, 17, 829-834. [CrossRef]

52. Jackson, R.B.; Canadell, J.; Ehleringer, J.R.; Mooney, H.A.; Sala, O.; Schulze, E.D. A global analysis of root distributions for terrestrial biomes. Oecologia 1996, 108, 389-411. [CrossRef] [PubMed]

53. Chen, Z.L.; Wang, Y.B.; Liu, H.; Xiao, Q.F. Prediction of Underground Space Needs. Planners 2007, 10, 9-13.

54. Guo, C.F.; Ye, F.; Zhang, J.L. Demand forecasting and demand distributional system development method of urban underground space. J. Chang. Univ. 2012, 32, 58-64.

55. Yuan, H.; Zhao, S.C.; Dai, Z.Z. On the urban spatial attribute and essential significance of underground space. Urban Plan. Forum 2013, 1, 85-89.

56. Chen, Z.L. Urban Underground Space Planning; Southeast University Press: Nanjing, China, 2005.

57. Zhou, D.K.; Li, X.Z.; Wang, Q.; Wang, R.; Wang, T.D.; Gu, Q.; Xin, Y.X. GIS-based urban underground space resources evaluation toward threedimensional land planning: A case study in Nantong, China. Tunn. Undergr. Space Technol. 2019, 84, 1-10. [CrossRef]

58. Peng, J.; Peng, F.-L. A GIS-based evaluation method of underground space resources for urban spatial planning: Part 2 application. Tunn. Undergr. Space Technol. 2018, 77, 142-165. [CrossRef]

59. Shao, J.Z.; Hu, Z.Y. Study on multiple coupling theory of urban underground space and aboveground space. Chin. J. Undergr. Space Eng. 2017, 13, 1431-1443.

60. Aitchison, C.; MacLeod, N.E.; Macleod, N.E.; Shaw, S.J. Leisure and Tourism Landscapes: Social and Cultural Geographies; Routledge: Oxford, UK, 2014.

61. Sørensen, M.L.S.; Carman, J. Heritage Studies: Methods and Approaches; Routledge: Oxford, UK, 2009.

62. Zhai, B.Q.; Ng, M.K. Urban Regeneration and Its Realities in Urban China. Urban Plan. Forum 2009, $2,75-82$.

63. Qian, Q.H. Present state, problems and development trends of urban underground space in China. Tunn. Undergr. Space Technol. 2016, 55, 280-289.

64. Childers, D.; Pickett, S.T.; Grove, J.M.; Ogden, L.; Whitmer, A. Advancing urban sustainability theory and action: Challenges and opportunities. Landsc. Urban Plan. 2014, 125, 320-328. [CrossRef]

65. Martin, N.J.; Rice, J.; Lodhia, S. Sustainable Development Planning: A Case of Public Participation using Online Forums. Sustain. Dev. 2012, 22, 265-275. [CrossRef] 